\title{
Vulnerability of Mossy Fiber Targets in the Rat Hippocampus to Forebrain Ischemia
}

\author{
M. Hsu and G. Buzsáki \\ Center for Molecular and Behavioral Neuroscience, Rutgers, The State University of New Jersey, Newark, \\ New Jersey 07102
}

Much of the work on forebrain ischemia in the hippocampus has focused on the phenomenon of delayed neuronal death in CA1. It is established that dentate granule cells and CA3 pyramidal cells are resistant to ischemia. However, much less is known about interneuronal involvement in CA3 or ischemic injury in the dentate hilus other than the fact that somatostatin neurons in the latter lose their immunoreactivity. We combined two sensitive methods-heat-shock protein (HSP72) immunocytochemistry and a newly developed Gallyas silver stain for demonstrating impaired cytoskeletal elements - to investigate the extent of ischemic damage to CA3 and the dentate hilus using the four-vessel-occlusion model for inducing forebrain ischemia. HSP72-like immunoreactivity was induced in neuronal populations previously shown to be vulnerable to ischemia. In addition, a distinct subset of interneurons in CA3 was also extremely sensitive to ischemia, even more so than the CA1 pyramidal cells. These neurons are located in the stratum lucidum of CA3 and possess a very high density of dendritic spines. In silver preparations, they were among the first to be impregnated as "dark" neurons, before CA1 pyramidal cells; microglial reaction was also initiated first in the stratum lucidum of CA3. Whereas CA1 damage was most prominent in the septal half of the hippocampus, hilar and CA3 interneuronal damage had a more extensive dorsoventral distribution. Our results also show a far greater extent of damage in hilar neurons than previously reported. At least four hilar cell types were consistently compromised: mossy cells, spiny fusiform cells, sparsely spiny fusiform cells, and long-spined multipolar cells. A common denominator of the injured neurons in CA3 and the hilus was the presence of spines on their dendrites, which in large part accounted for the far greater number of mossy fiber terminals they receive than their nonspiny neighbors. We suggest that the differential vulnerability of neuronal subtypes in these two regions may be attributed to their extremely dense innervation by the mossy fibers and/or the presence of non-NMDA receptor subtypes that are highly permeable to calcium. In addition, early impairment of these spiny CA3 cells and hilar neurons after ischemia may be causal to delayed neuronal death in the CA1 pyramidal cells.

\footnotetext{
Received Nov. 27, 1992; revised Mar. 22, 1993; accepted Mar. 30, 1993.

We thank Drs. W. A. Pulsinelli, T. F. Freund, S. M. Zola-Morgan, and P. Alvarez-Royo for their comments on the manuscript. This work was supported by NIH (NS27058, 28121, 02383), HSFP, and the Whitehall Foundation. M.H. was supported in part by the Epilepsy Foundation of America.

Correspondence should be addressed to György Buzsáki, Center for Molecular and Behavioral Neuroscience, Rutgers University, 197 University Avenue, Newark, NJ 07102.

Copyright $\mathcal{C} 1993$ Society for Neuroscience $0270-6474 / 93 / 133964-16 \$ 05.00 / 0$
}

IKey words: ischemia, hippocampus, dentate hilus, CA3, spiny interneurons, silver stain, heat-shock protein, microglia, kainate, mechanisms of cell death]

The pattern of neuronal death in the hippocampus following cerebral ischemia has been well described in the rat (Pulsinelli et al., 1982; Kirino et al., 1985; also see Schmidt-Kastner and Freund, 1991, for a review), gerbil (Kirino, 1982; Crain et al., 1988), primate (Zola-Morgan et al., 1992), and human (ZolaMorgan et al., 1986). Of the principal neurons, CAl pyramidal cells are the most sensitive while CA3 pyramidal cells and dentate granule cells are resistant. It has also been shown that a subpopulation of hilar interneurons that demonstrate somatostatin immunoreactivity is vulnerable to ischemia (Johansen et al., 1987, 1992). The somatostatin neurons degenerate within $24 \mathrm{hr}$ while CAl pyramidal cells take several days to die, the mechanism of this "delayed neuronal death" (Kirino, 1982) yet to be determined.

At present, one of the most prevalent hypotheses proposed to explain the selective vulnerability of hippocampal neurons is the "excitotoxic hypothesis" of Olney (1978), which postulates that an increase in the release of excitatory amino acids leads to neuronal death by allowing a lethal entry of calcium into the postsynaptic cell via NMDA-gated ion channels (MacDermott et al., 1986; Siesjö and Bengtsson, 1989). This hypothesis is supported by the findings that CA1 has the highest density of NMDA receptors in the hippocampus (Monaghan et al., 1983; Cotman et al., 1987), and by the observations of a transient increase in glutamate release following ischemia (Benveniste et al., 1984) and that neuronal damage is attenuated by lesioning the major excitatory inputs to the hippocampus (Johansen et al., 1986; Kaplan et al., 1989). On the other hand, recent electrophysiological studies have consistently failed to demonstrate any hyperexcitability in the hippocampus prior to CA1 cell loss (Buzsáki et al., 1989; Imon et al., 1991; Jensen et al., 1991). Furthermore, many of the neuroprotective effects of NMDA antagonists in severe global ischemia (Simon et al., 1984; Gill et al., 1987; Swan et al., 1988; Ikonomidou et al., 1989; Olney et al., 1989) have now been attributed to hypothermia (Corbett et al., 1990; Buchan et al., 1991a,b; Buchan, 1992). A second hypothesis of ischemic cell vulnerability focuses on the chemical content of the affected neurons. Because an accumulation of calcium is implicated in excitotoxic cell death (Greenamyre, 1986; Choi, 1988), many studies have attempted to correlate the vulnerability of neurons with the presence or absence of the calcium-binding proteins parvalbumin and calbindin because of their calcium-buffering abilities (Nitsch et al., 1989b; Sloviter, 1989; Johansen et al., 1990). Indeed, intracel- 
lular injection of the calcium chelator BAPTA effectively protected neurons from stimulation-induced cell death in vitro (Scharfman and Schwartzkroin, 1989). However, studies that systematically examined the relationship between the distribution of calcium-binding proteins and neuronal vulnerability have failed to demonstratc such a relationship in either forebrain ischemia (Freund et al., 1990; Johansen et al., 1990) or epilepsy (Freund et al., 1991). Furthermore, neuronal neuropeptide content (somatostatin, neuropeptide Y, cholecystokinin, or vasoactive intestinal peptide) has also failed to predict susceptibility to an ischemic insult (Yanagihara et al., 1985; Grimaldi et al., 1990). A third hypothesis that has so far received little attention is the location of susceptible neurons within the hippocampal network being the primary determinant of ischemic vulnerability.

To date, the majority of studies have concentrated on the phenomenon of delayed neuronal death in the CA1 pyramidal cells. The CA3 region has been regarded to be resistant to ischemic cell damage partly due to the fact that excitatory synaptic transmission is achieved via kainate/ $\alpha$-amino-3-hydroxy-5methyl-isoxazole-4-propionic acid (AMPA) rather than NMDA receptors (Cotman et al., 1987). And whilc CAl interneurons have been shown to survive an ischemic insult (Johansen et al., 1983; Nitsch et al., 1989a), there has been no study of the fate of CA3 interneurons or dentate hilar neurons. Furthermore, the mechanism of ischemic cell damage in the hilus is still unknown. Although it is well accepted that somatostatin neurons lose their immunoreactivity, the extent of ischemic damage in other hilar cells, of which there are over 20 morphological types (Amaral, 1978), has not been investigated.

Recent studies on the role of the nonconstitutive $72 \mathrm{kDa}$ heatshock protein (HSP72) following experimental stroke have focused on its induction in the principal cells of the rat hippocampus, that is, CA1 and CA3 pyramidal cells, granule cells, and to some extent the polymorphic cells of the hilus (Nowak, 1985; Dienel et al., 1986; Vass et al., 1988; Chopp et al., 1991; Gonzalez et al., 1991; Simon et al., 1991). Although the exact role of HSP72 is still unclcar (Pclham, 1986), its expression in the principal cells of the hippocampus correlates with the latter's vulnerability to cerebral ischemia (Nowak, 1985; Vass et al., 1988; Gonzalez et al., 1991; Simon et al., 1991) as well as other disease states, for example, status epilepticus (Vass et al., 1989; Sloviter and Lowenstein, 1992) and neonatal hypoxia (Dwyer et al., 1989). In the present study, we combined a recently developed silver stain for visualizing traumatized neurons (Gallyas et al., 1990; Van den Pol and Gallyas, 1990) and immunocytochemistry for HSP72 to examine the extent of damage in the dentate hilus and in CA3. Both methods allow direct visualization of compromised neurons in a Golgi-like manner. Our findings suggest that neuronal vulnerability in CA3 spiny interneurons and hilar spiny cells is a function of the density of mossy fiber innervation they receive. Ischemic cell damage in this instance is hence non-NMDA-related and not correlated with the presence or absence of somatostatin and/or calcium-binding proteins.

\section{Materials and Methods}

Induction of transient forebrain ischemia. Female Wistar rats (200-275 gm) were used in the experiments. Transient forebrain ischemia was induced using a modification (Pulsinelli and Buchan, 1988) of the fourvessel-occlusion (4VO) method of Pulsinelli and Brierley (1979). The animals were anesthetized with a mixture of ketamine $(25 \mathrm{mg} / \mathrm{ml})$,
Rompun $(1.3 \mathrm{mg} / \mathrm{ml})$, and acepromazine $(0.24 \mathrm{mg} / \mathrm{ml})$ at a surgical dose of $4 \mathrm{ml} / \mathrm{kg}$.

The common carotids were first isolated through a ventral midline neck incision by placing atraumatic Silastic tuhes around both arteries A silk ligature was then passed anterior to the cervical and paravertebral muscles but posterior to the trachea, esophagus, external jugular veins, and common carotids. The incision was then closed and the ends of the ligature secured to the nape of the neck by tape. A second incision was made behind the occipital bone and the paraspinal muscles separated to expose the alar foramina. The vertebral arteries running in the foramina transversaria were then electrocauterized under direct visual control. Animals were allowed to recover overnight, during which food was withheld but free access to water allowed. For occlusion of the carotids, the ventral neck wound was injected with $1 \%$ lidocaine and reopened. The common arteries were then occluded by microaneurysm clips. Only animals that showed a complete loss of righting reflex throughout the duration of the carotid occlusion were included in the study. The ligature around the neck was tightened for those animals that met criterion to restrict collateral blood flow further. The microaneurysm clips were removed after either $8 \mathrm{~min}(n=16)$ or $15 \mathrm{~min}(n$ $=20$ ) of occlusion. Rats were monitored throughout the ischemic period and ischemia was discontinued in those animals with respiratory difficulties. At the end of the ischemic period, the ligature was cut, the wound closed, and the rats closely observed until they walked spontaneously.

Perfusion-fixation. Animals were perfused after either $12 \mathrm{hr}[n=3$ (8 min), 5 (15 min)], $24 \mathrm{hr}(n=4,8), 48 \mathrm{hr}(n=6,3)$, or $96 \mathrm{hr}(n=$ 5,5 ) of reperfusion. Three different perfusion-fixation procedures were used. For demonstration of HSP72 immunocytochemistry, animals were deeply anesthetized and perfused through the aorta with $0.9 \%$ saline followed by $4 \%$ paraformaldehyde ( $\mathrm{pH} 7.2$ ). Brains were removed, postfixed for 0-4 hr, and cryoprotected in a solution of 30\% sucrose in phosphate buffer (PB) overnight. Fifty micrometer sections were then cut on a freezing microtome and a $1-i n-4$ series collected in PB for immunocytochemistry.

For demonstration of both silver-impregnated ("dark") neurons and HSP72 immunocytochemistry, animals were perfused through the aorta first with cacodylate-buffered saline ( $\mathrm{pH} 7.5$ ) followed by a cacodylatebuffered fixative containing $4 \%$ paraformaldehyde and $5.9 \%$ calcium chloride ( $\mathrm{pH} 7.5$ ). Brains were left in situ for $4 \mathrm{hr}$, removed, and then postfixed in the same solution overnight. Following overnight cryoprotection in $30 \%$ sucrose, a 1 -in-3 series was cut on a freezing microtome: the first section was cut at $50 \mu \mathrm{m}$ and collected in PB for HSP72 immunocytochemistry; the second section was cut at $75 \mu \mathrm{m}$ and collected in the cacodylate fixative for silver staining; and the third section was cut at $50 \mu \mathrm{m}$ and stored in cryoprotectant for later use.

Finally, eight animals were perfused with cacodylate fixative at $1 \mathrm{~d}$ to 1 month after $15-20 \mathrm{~min}$ of $4 \mathrm{VO}$ for demonstration of dark neurons, microglial reaction, and silver impregnation of degenerating terminals. In these cases, the brains were left in situ overnight after perfusion before removal from the skull. They were then left in the perfusion fixative for 1 week before sectioning at $80 \mu \mathrm{m}$ on a freezing microtome. Three unoperated control animals were also perfused for Timm histochemistry to demonstrate the mossy fiber termination zone (see below).

Heat-shock protein immunocytochemistry. Immunoprocessing was carried out according to the method of Gonzalez et al. (1991) following a modification of a protocol kindly provided to us by Dr. Frank Sharp (University of California at San Francisco). Tissue sections were extensively washed in $\mathrm{PB}$. After $2 \mathrm{hr}$ in a blocking solution of $10 \%$ normal horse serum (NHS), $0.3 \%$ Triton X-100 (TX100), $0.1 \%$ bovine serum albumin (BSA), sections were incubated for $36 \mathrm{hr}$ at $4^{\circ} \mathrm{C}$ in the monoclonal antibody raised against HSP72 (Amersham Corp) at 1:4000 in $2 \%$ NHS, $0.3 \%$ TX $100,0.1 \%$ BSA. Sections were then rinsed in PB 3 $\times 10 \mathrm{~min}$ and reacted at room temperature using a Vectastain Kit (Vector Laboratories, Burlingame, CA).

"Dark" neurons. Demonstration of traumatized "dark neurons" was carried out using a recently developed silver impregnation method for demonstrating cytoskeletal damage (Gallyas et al., 1990). Sections were dehydrated in a graded 1-propanol series and incubated at $56^{\circ} \mathrm{C}$ for 16 $\mathrm{hr}$ in an esterifying solution consisting of $1.2 \% \mathrm{H}_{2} \mathrm{SO}_{4}$ and $98 \%$ 1 -propanol. After a 10 min treatment in $8 \%$ acetic acid, sections were developed in a silicotungstate physical developer. Development was terminated by washing in $1 \%$ acetic acid for $30 \mathrm{~min}$. Sections were then dehydrated, mounted, and coverslipped with DPX.

Microglia staining. Adjacent sections from the material stained for 

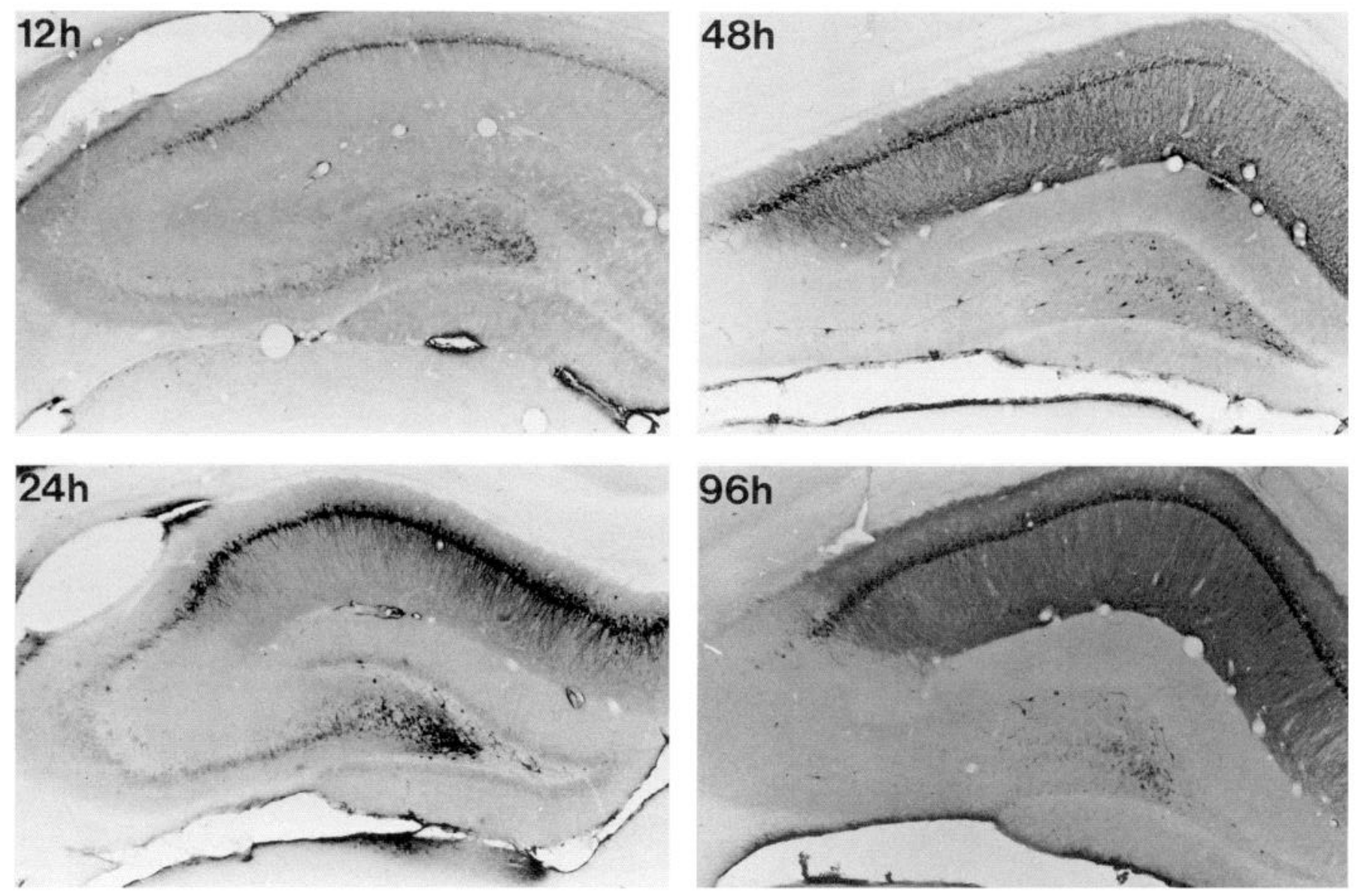

Figure 1. Time course of HSP72 expression: 12, 24, 28, and $96 \mathrm{hr}$ after $4 \mathrm{VO}$ ischemia. HSP72 expression was minimum at $12 \mathrm{hr}$, and peaked at $24 \mathrm{hr}$ in the hilus and $48 \mathrm{hr}$ in stratum lucidum interneurons in CA3. HSP72 expression in CA1 was similar to that described by Simon et al. (1991).

"dark" neurons were used. Briefly, sections were rinsed $3 \times 5 \mathrm{~min}$ in $\mathrm{dH}_{2} \mathrm{O}$ and then left in a pretreating solution $\left(100 \mathrm{ml} \mathrm{dH}_{2} \mathrm{O}, 0.3 \mathrm{ml}\right.$ $\mathrm{H}_{2} \mathrm{SO}_{4}, 0.2 \mathrm{ml}$ concentrated $\mathrm{H}_{2} \mathrm{O}_{2}$ ) for $16-24 \mathrm{hr}$ at room temperature. After washing in $\mathrm{dH}_{2} \mathrm{O} 3 \times 5 \mathrm{~min}$, sections were placed in a second

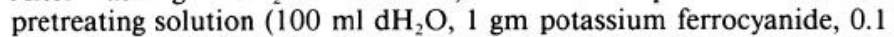
ml concentrated $\mathrm{H}_{2} \mathrm{SO}_{4}$ ) for $10-30 \mathrm{~min}$. Sections were then washed again in $\mathrm{dH}_{2} \mathrm{O}$, after which they were developed in the silicotungstate developer for the "dark" neurons. Development was terminated by washing in $1 \%$ acetic acid for $30 \mathrm{~min}$.

Silver staining of degenerating terminals. The method of Gallyas et al. (1980) was used. Briefly, this consisted of treatment for $2 \times 5 \mathrm{~min}$ in a preprocessing solution $\left(2 \% \mathrm{NaOH}, 2.5 \% \mathrm{NH}_{4} \mathrm{OH}\right), 10 \mathrm{~min}$ in an impregnating bath $\left(0-0.8 \% \mathrm{NaOH}, 2.5 \% \mathrm{NH}_{4} \mathrm{OH}, 0.5 \% \mathrm{AgNO}_{3}\right), 3 \times$ $5 \mathrm{~min}$ in an intermediate solution $\left(0.5 \% \mathrm{Na}_{2} \mathrm{CO}_{3}, 0.01 \% \mathrm{NH}_{4} \mathrm{NO}_{3}\right.$ in $30 \%$ ethanol), and $1 \mathrm{~min}$ in a developing solution $(0.4-0.6 \%$ formaldehyde, $0.01 \%$ citric acid in $10 \%$ ethanol), followed by $3 \times 10 \mathrm{~min}$ wash in $0.5 \%$ acetic acid. The sections were then mounted, dehydrated, and coverslipped using DPX.

Timm histochemistry. Timm staining according to Danscher (1981) as modified by Sloviter (1982) was performed on unoperated control rats to demonstrate the extent of the hippocampal mossy fiber projection. Rats were deeply anesthetized and perfused through the aorta with $0.37 \%$ sulfide solution $(\mathrm{pH} 7.2$ ) for 5 min followed by $10 \%$ neutral buffered formalin ( $\mathrm{pH} 7.2$ ) for 15 min. Brains were then removed from the skull and placed in the fixative for $24 \mathrm{hr}$, after which they were transferred to $30 \%$ sucrose in PB for overnight cryoprotection. Forty micrometer sections were then cut on a freezing microtome, mounted on gelatin-coated slides, and air-dried overnight. The sections were developed at $26^{\circ} \mathrm{C}$ for $30-60 \mathrm{~min}$ in the dark in a freshly prepared developer made up of $240 \mathrm{ml}$ of $50 \%$ gum arabic, $40 \mathrm{ml}$ of citrate solution $(9.4 \mathrm{gm}$ of sodium citrate plus $10.2 \mathrm{gm}$ of citric acid monohydrate), $120 \mathrm{ml}$ of $5.7 \%$ hydroquinone solution, $2.0 \mathrm{ml}$ of $17 \%$ silver nitrate. After development, slides were rinsed in running water for 30 min, dehydrated, and coverslipped.

Characterization of immunolabeled and silver-impregnated neurons. Several HSP72-immunoreactive interneurons in the CA3 area and dentate hilus in addition to some silver-impregnated CA 3 interneurons were drawn with the aid of a camera lucida using a $40 \times$ or $100 \times$ objective. Different cell types in the dentate hilus from the specimens stained for HSP72-like immunoreactivity and the "dark" neuron stain were identified according to Amaral (1978).

Quantification of CA3 and hilar damage. HSP72-immunopositive cell bodies were counted using a $10 \times$ objective under light microscopy with the aid of an image analysis system (Macintosh, IMAGE software) from coronal sections obtained at four different levels according to Paxinos and Watson (1986; AP $=-2.8,-3.8,-4.8-6.04 \mathrm{~mm}$ from bregma) along the rostral-caudal extent of the hippocampus. In area CA3, spiny interneurons in the stratum lucidum were counted and reported as mean cell number per section. In the dentate gyrus, the hilus proper (zone 4 of Amaral, 1978) was outlined and its area computed using the image analysis system; the number of labeled cells was counted in the dorsal hippocampus, and the extent of hilar involvement in each section was then expressed as the number of immunopositive cell bodies per $\mathrm{mm}^{2}$. In all cases, each hemisphere was treated separately in the final analysis.

\section{Results}

In sections from both unoperated and sham-operated controls neural elements did not demonstrate any HSP72 immunoreactivity. As previously described, some ependymal cells lining the ventricles (Vass et al., 1988) and capillary endothelial cells were lightly immunopositive(Gonzalez et al., 1991). Control sections incubated without the primary antibody showed no immuno- 


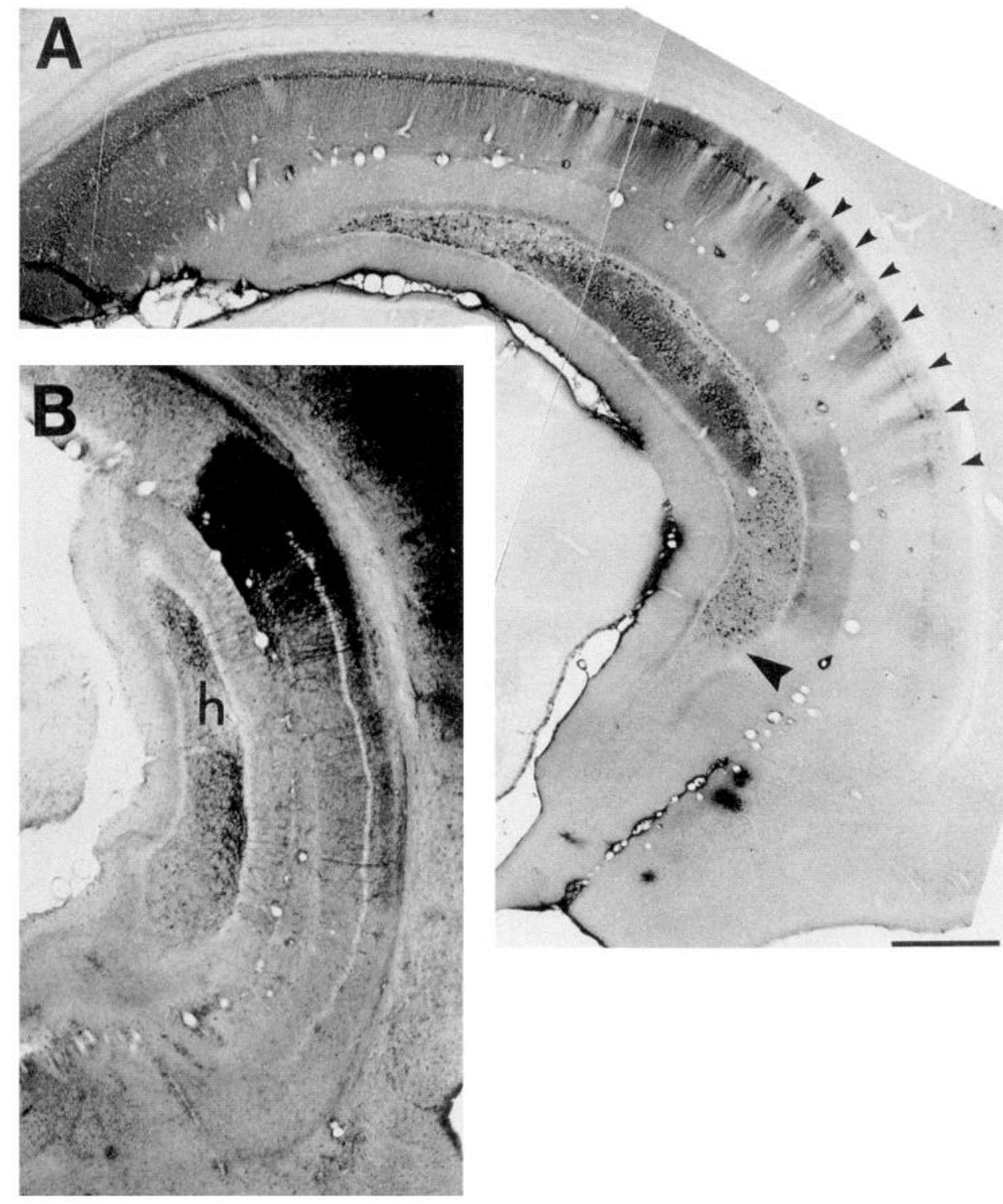

Figure 2. Spatial distribution of ischemic damage. $A$, HSP72 immunoreactivity $(15 \mathrm{~min}$ of ischemia, $1 \mathrm{~d}$ survival). Section along the longitudinal axis of the hippocampus showing dorsal-ventral gradient of ischemic cell damage in CA1. Arrowheads indicate periodicity of neuronal damage at 500 $800 \mu \mathrm{m}$ intervals. Note uniform damage in the dentate hilus. $B$, "Dark" neuron method (15 min ischemia, $2 \mathrm{~d}$ survival). Coronal section at the posterior curvature. Note dorsal-ventral gradient in $\mathrm{CA} 1$ and the more extensive damage of hilar neurons in the ventral half of the hippocampus (large arrowhead in $A$ ) as revealed by both methods. $h$, hilus. Scale bar, $1 \mathrm{~mm}$. reactivity. The distribution and time course of induction of Golgi-like HSP72-immunostained neurons were similar to that observed in previous studies using 4VO (Fig. 1; Simon et al., 1991) and two-vessel occlusion (Chopp et al., 1991; Gonzalez et al., 1991) models of ischemia. In general, there was a good correspondence between the induction of HSP72 immunoreactivity and silver impregnation; that is, HSP72 immunoreactivity was only seen in those neuronal populations that were also silver stained in separate or in the same preparations (Fig. 2). In both cases, the dorsal half of CAl was mainly affected while hilar damage extended more ventrally. Furthermore, in the section processed for HSP72 immunocytochemistry, a periodicity of staining was seen at 500-800 $\mu \mathrm{m}$ intervals (Fig. 2A).

Animals subjected to $15 \mathrm{~min}$ of ischemia typically demonstrated hilar cell damage within $24 \mathrm{hr}$ (Fig. $3 A$ ) and CAl cell damage after 3-4 d (Fig. 3B). Damaged neurons were silverstained in a Golgi-like manner. The general pattern of ischemic cell damage using our silver impregnation technique (M. Hsu, F. Gallyas, and G. Buzsáki, unpublished observations) is consistent with previous results (Pulsinelli et al., 1982; SchmidtKastner and Freund, 1991).

\section{Impairment of CA3 interneurons after ischemia}

At 1 and $2 \mathrm{~d}$ postischemia, a distinct population of interneurons located in the stratum lucidum of CA3 was strongly immunoreactive for HSP72 (Figs. $4 A, D, 5$ ). These cells could also be seen in silver-stained sections (Fig. 6). They were present throughout the septotemporal extent of the hippocampus, but the optimal area to visualize them was in the posterior hippocampus where the stratum lucidum divided the dorsal and ventral CA3 (Fig. $4 B$ ) and also at the occipital bend (Fig. $4 C$ ). In the rostral CA3 their dendrites followed the curvature of the hippocampus. Timm staining confirmed that these neurons were restricted to the termination zone of the mossy fibers (Fig. $4 E-$ $G)$. Their dendrites were oriented parallel to the pyramidal layer and spanned several hundred micrometers both in the septotemporal and transverse directions. The dendrites of these cells were covered with numerous spines (Figs. $4 D, 5$ ) with long necks and small spine heads. On some of the cells (Fig. $5 B$ ), spines could be seen even on the somata. Silver-impregnated interneurons in CA3 were very similar to those demonstrated using HSP72 immunocytochemistry. Although spines could not be 

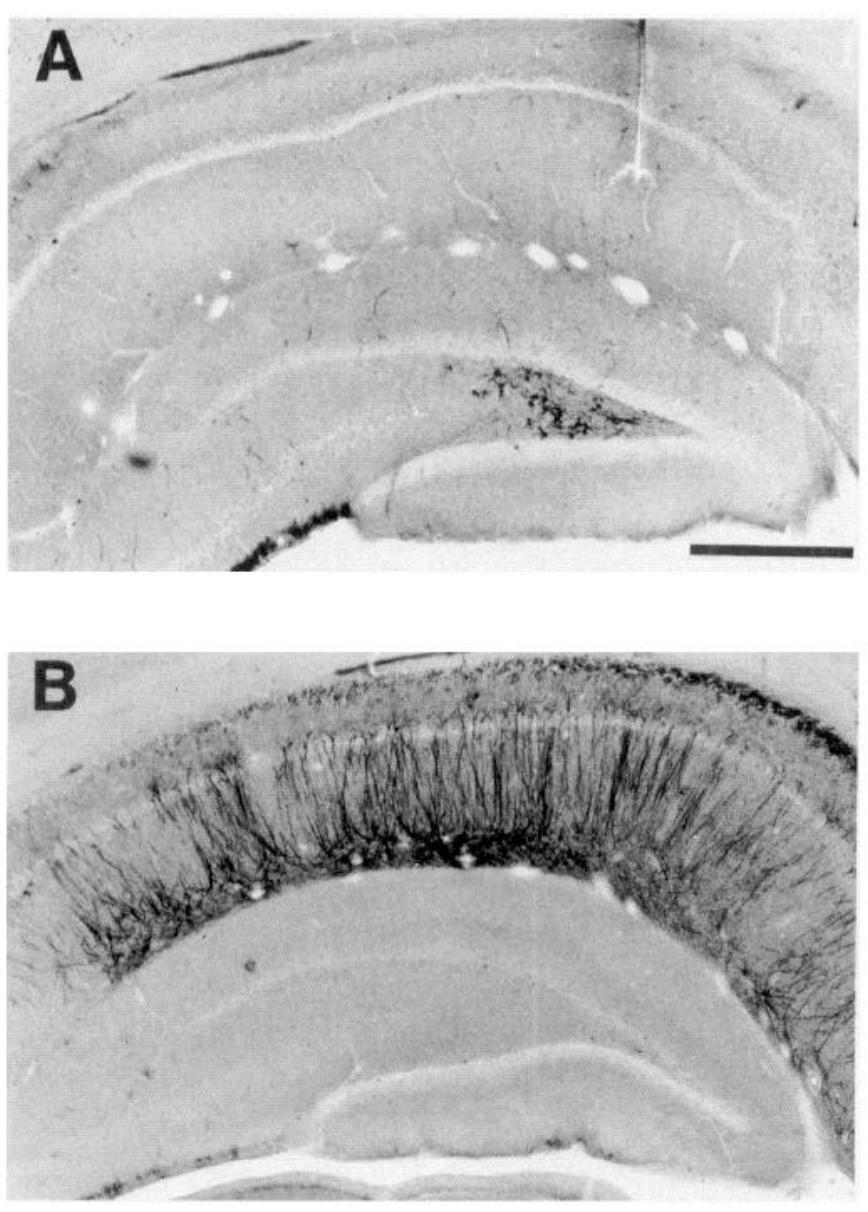

Figure 3. Ischemic cell damage in the dorsal hippocampus demonstrated by the dark neuron method. $A$, One day postischemia. Only neurons in the dentate hilus are silver-impregnated. $B$, Four days postischemia. Note Golgi-like impregnation of degenerating CAl pyramidal cells; hilar neurons are no longer visible. Duration of ischemia, $15 \mathrm{~min}$ in $A$ and $B$. Scale bar, $500 \mu \mathrm{m}$.

clearly distinguished, it was evident that both somata and the long dendrites of these cells were restricted to the stratum lucidum. In all appearances, they resembled the calretinin-immunoreactive spiny cells described by Gulyás et al. (1992).

A three-way ANOVA was performed on HSP72-immunoreactive CA3 spiny interneurons and hilar cells (see below) with duration of carotid occlusion, survival time, and the four rostrocaudal hippocampal levels as dependent variables. Overall, there were significantly more labeled cells in the 15 min group relative to the group with the shorter occlusion time $[F(1,240)$ $=9.693, p<0.002]$. Although the number of labeled cells peaked at $24 \mathrm{hr}$ for the $8 \mathrm{~min}$ group, the greatest number of cells - a twofold increase over that in the former-was observed at $48 \mathrm{hr}$ postischemia in the $15 \mathrm{~min}$ group $[F(3,240)=21.932$, $p<0.0001$; Fig. 7A]. The number of immunoreactive cells increased with the area of stratum lucidum present at each level and thus was greatest at the two caudal levels $[F(3.240)=11.704$, $p<0.0001$; Fig. $7 B$ ]. At $96 \mathrm{hr}$ postischemia, the number of labeled cells substantially decreased in both groups.

Labeling of CA3 pyramidal cells was only seen in some animals with severe ischemia. In cases with shorter occlusion times, labeling was indistinguishable from the weak background labeling and contrasted sharply with that of the strongly labeled interneurons. Within the CA3 region, there was a differential vulnerability: the $\mathrm{CA} 3 \mathrm{c}$ pyramids were more sensitive than those in CA3b or CA3a (Fig. $8 a-c$ ). Of the CA3c pyramidal cells, stellate-like pyramidal neurons and unaligned pyramidal cells in zone 3 of Amaral (1978) were the most sensitive to ischemia.

\section{Impairment of hilar neurons after ischemia}

In the dentate hilus, a heterogeneous population of neurons was immunoreactive for HSP72 (Fig. 9). The most common cell types labeled were the mossy cells and spiny fusiform cells (Fig. 9C-F; Amaral, 1978; Frotscher et al., 1991). In addition, many other cells of different morphologies were also immunoreactive. We identified six different cell types in zone 4 of Amaral (1978), all of which possessed spines on their dendrites and some on their somata. In addition to mossy cells and spiny fusiform cells, these included, in order of frequency of occurrence, sparsely spiny fusiform cells, long-spined multipolar cells, oviform cells, and spiny spheroid cells. The last of these resembled the aspiny spheroid cell at the dentate granule cell layer/hilus border (Amaral, 1978) with the exception that both soma and dendrites were covered with spines in our specimen (Fig. 9I-K). Granule cells were never stained.

A three-way ANOVA revealed no difference in the number of immunoreactive cells $/ \mathrm{mm}^{2}$ between the $8 \mathrm{~min}$ and $15 \mathrm{~min}$ groups, suggesting that the number of affected cells had already reached a maximum following $8 \mathrm{~min}$ of occlusion $(p=0.3)$. The number of labeled cells changed with survival time, increasing from a minimum at $12 \mathrm{hr}$ postischemia, reaching a peak at $24 \mathrm{hr}$, and then tapering off thereafter $[F(3,240)=32.182$, $p<0.0001$; Fig. 7A]. This trend was true for both occlusion groups, consistent with the idea that hilar cell involvement had already reached an asymptote with the shorter occlusion time. As in CA3, the greatest number of hilar cells was seen at the more caudal levels (AP $=-4.8$ and $-6.04 \mathrm{~mm}$, respectively) with fewer cells seen at the two rostral levels $[F(3,240)=7.744$, $p<0.0001$; Fig. 7B].

HSP72 immunoreactivity was also evident in a fiber plexus in the inner molecular layer of the dentate gyrus (Fig. $8 c, d$ ), the terminal zone of mossy cells and other hilar cells with association projections (Han et al., 1993). No labeling was evident in

Figure 4. HSP72 immunoreactivity in CA3 stratum lucidum interneurons. A, Section through rostral hippocampus showing immunoreactive CA1 and CA2 (delineated by arrowheads) pyramidal cells, faint staining of CA3 pyramidal cells, and strong staining of interneurons located in the stratum lucidum. Double arrowhead, CA1-CA2 border; large arrowhead, CA2-CA3 border. $B$ and $C$, Coronal sections through the posterior hippocampus where dorsal and ventral $C A 3$ are divided by stratum lucidum $(B)$ and near the occipital bend $(C)$. $l u$, stratum lucidum; $r$, stratum radiatum. $D$, Stratum lucidum interneurons from another animal at higher magnification. In this section, there is very little background staining and only the interneuronal somata and their spiny dendrites are stained. $p$, pyramidal layer. Inset shows dendritic spines from one interneuron at higher magnification. Arrowheads point to spine heads. $E-G$. Timm staining of corresponding sections illustrated in $A-D$ showing termination zone of the mossy fiber $(m f)$ system in the stratum lucidum. $E$, Rostral section. $F$ and $G$, Posterior CA3 where stratum lucidum divides dorsal from ventral CA3 $(F)$ and near the occipital bend $(G)$. Arrowheads, CA2-CA3 border. Scale bar: $200 \mu \mathrm{m}$ for $A-C ; 50 \mu \mathrm{m}$ for D; $400 \mu \mathrm{m}$ for $E-G$. 

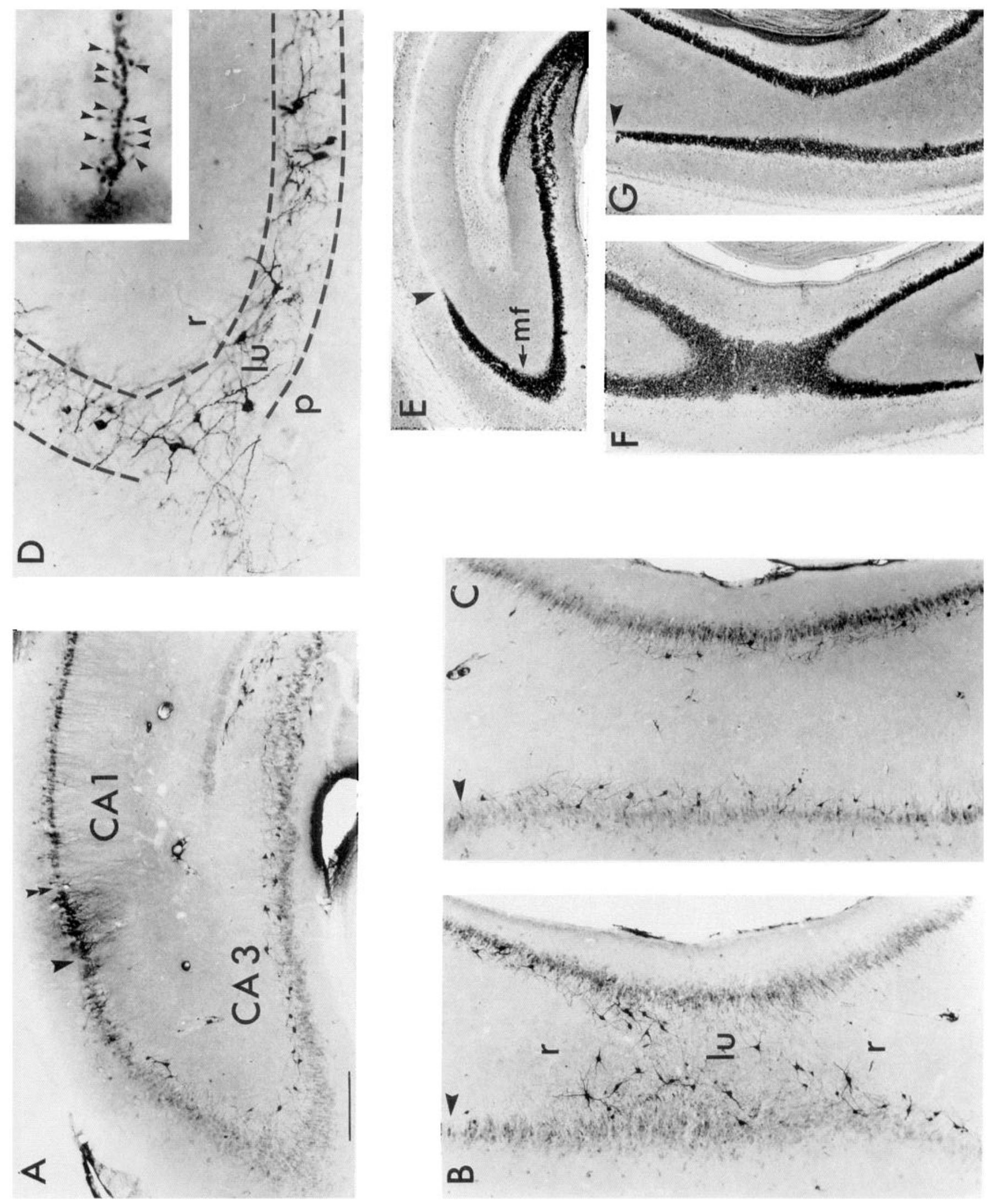

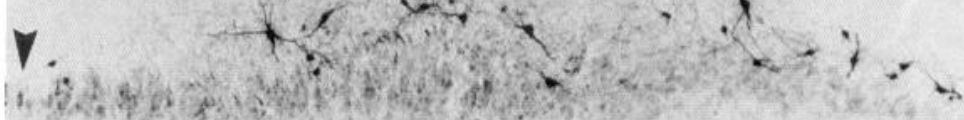
$\infty$ 

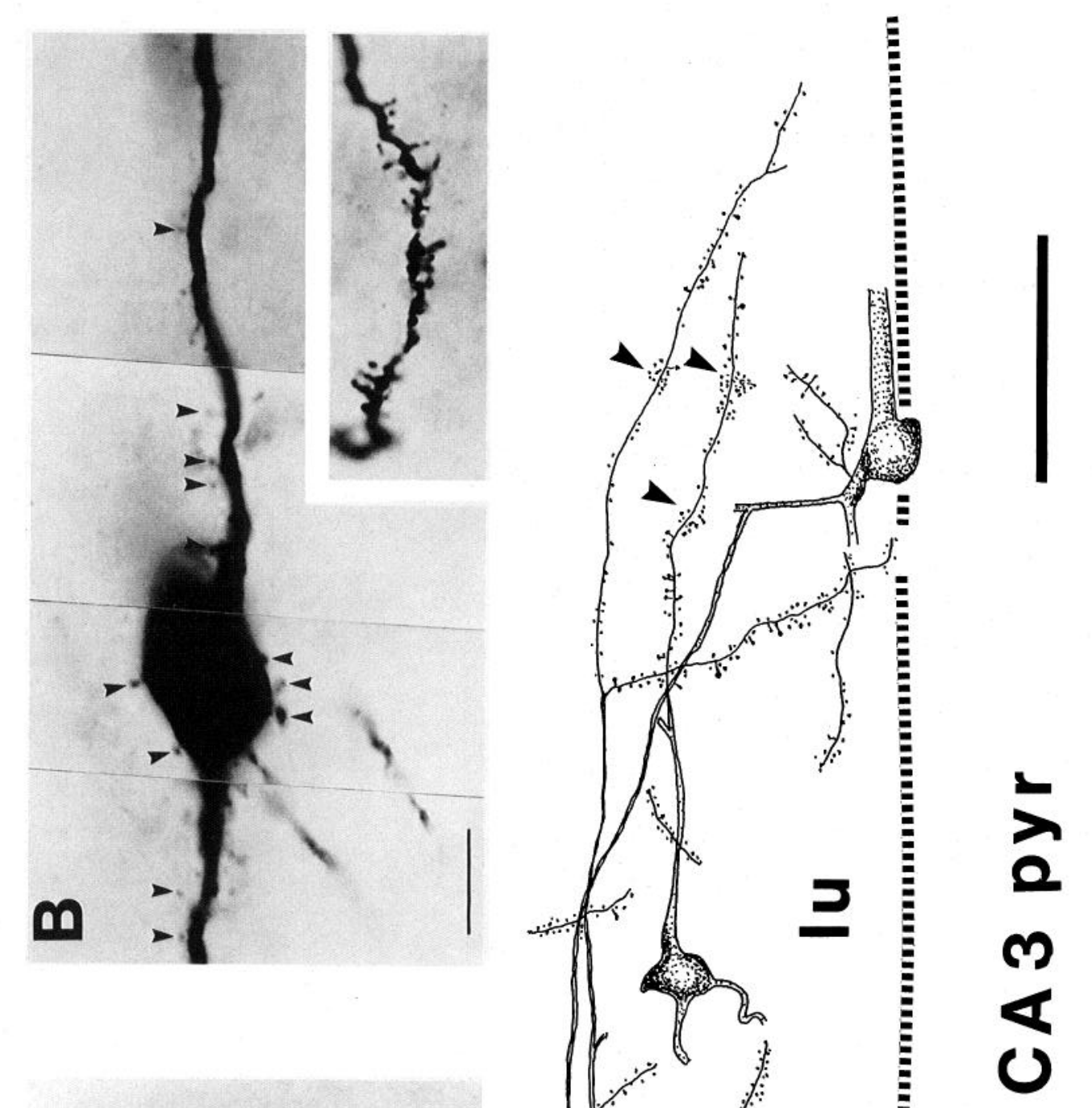

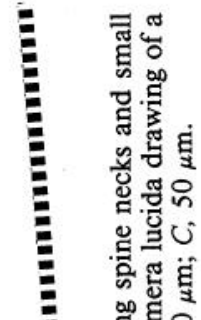

므의응

\#

E हैं

-

ही

离.

कीष

हैं

엉융

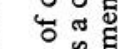

응 㟧

空

स造

तิ

空穿总

宓安

ษึี

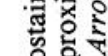

年

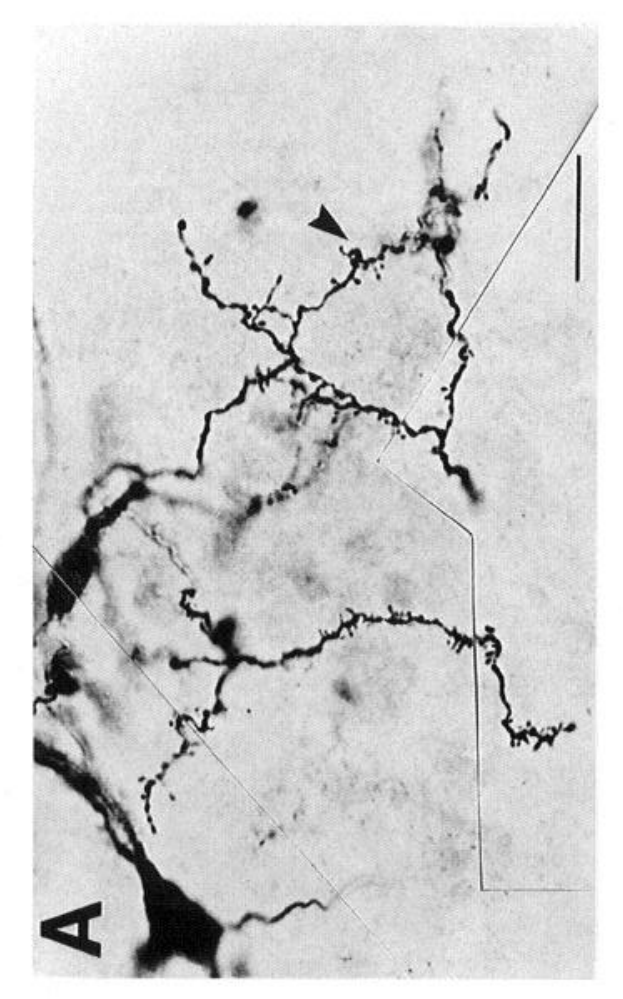

(1)

톯ำ

뎐



害害

통혀

吉边

동즐

氖表

통

헙 긍.

象.

낭 의

氙逮

동뮴

窟

额哭

氙.

( 1 E 


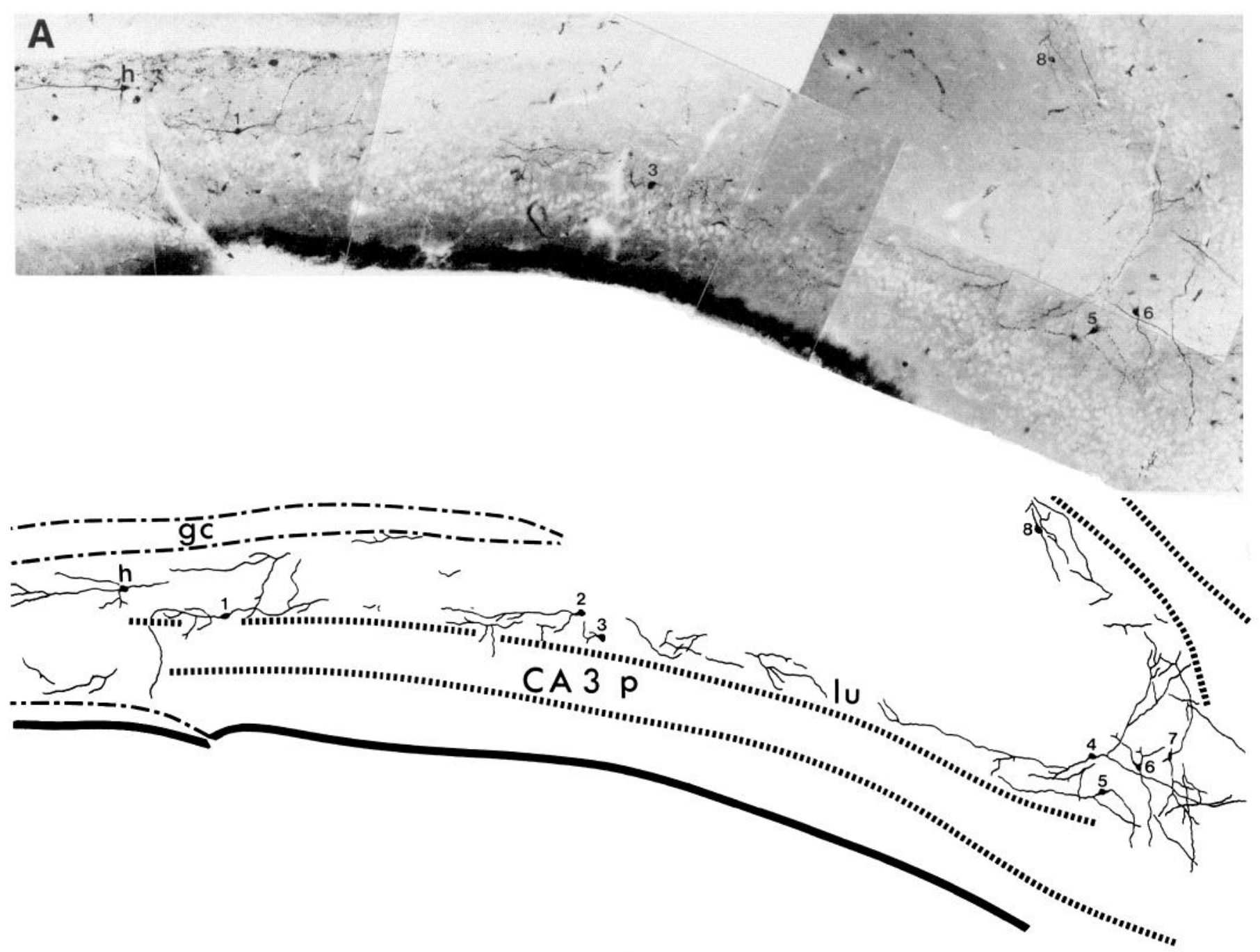

Figure 6. Selective impairment of CA3 stratum lucidum interneurons. $A$, "Dark" neuron stain. $B$, Camera lucida drawing showing details of the cells numbered from 1 to 8 in $A$. Neurons 2,4 , and 7 are not visible in the plane of focus in $A$. Note horizontal dendrites ramifying within the stratum lucidum. $g c$, granule cell layer; $h$, hilus; $l u$, stratum lucidum; $C A 3 p$, CA3 pyramidal layer.

either the middle or outer thirds of the molecular layer. This HSP72-immunopositive band corresponded to the band of argyrophilia in the inner molecular layer of the dentate gyrus seen 1 week after ischemia using the Gallyas silver stain for degenerating terminals (Fig. $8 a$ ).

\section{Neuropathological signs of cell damage}

As early as $1 \mathrm{~d}$ after ischemia, the dendrites of some immunolabeled neurons in the hilus and CA 3 appeared pathological. Many of the spiny dendrites contained uneven beads or large vacuoles with little or no cytoplasmic bridges (Fig. 10A,B). In silver-impregnated material, these beaded dendrites could also be seen (Fig. 10C), again with incomplete or complete interruption of the cytoplasm. As described above, visualization of dendrites of spiny neurons in CA3 was more difficult after longer durations of ischemia using HSP72 immunocytochemistry. Similarly, silver-impregnated neurons were rarely seen with the "dark" neuron method after $15 \mathrm{~min}$ of ischemia. In this context, it is important to emphasize that following more severe ischemia (>20 min) both HSP72 immunocytochemistry and the "dark" neuron method failed to stain CA1 neurons, even though these cells are known to degenerate (Gonzalez et al., 1991; M. Hsu and G. Buzsáki, unpublished observations). Support for the permanent damage/loss of spiny CA3 cells comes from silver staining of reactive microglia. At 1 month postischemia, reactive microglia were present both in the cell layer and neuropil of CAl in animals that showed bilateral cell loss but not in shamoperated controls (not shown). In addition, there was intense microglia staining in the stratum lucidum of CA3 as well as in the hilus (Fig. 8e,f). These microglia were bigger in size and darker, and had more processes than other microglia seen occasionally in other regions, indicating that they were activated microglia.

\section{Discussion}

The present results show that ischemic damage in the hilus is more extensive and involves many more cell types than previously shown. Even more important, they demonstrate ischemic vulnerability in area CA3 that has never been described before; that is, a subpopulation of interneurons restricted to the stratum lucidum is selectively damaged in the absence of any other CA3 involvement. Because both the hilar cells and CA3 interneurons possess spines on their dendrites and are thus densely innervated by the mossy fibers, we suggest that the 
A hilus
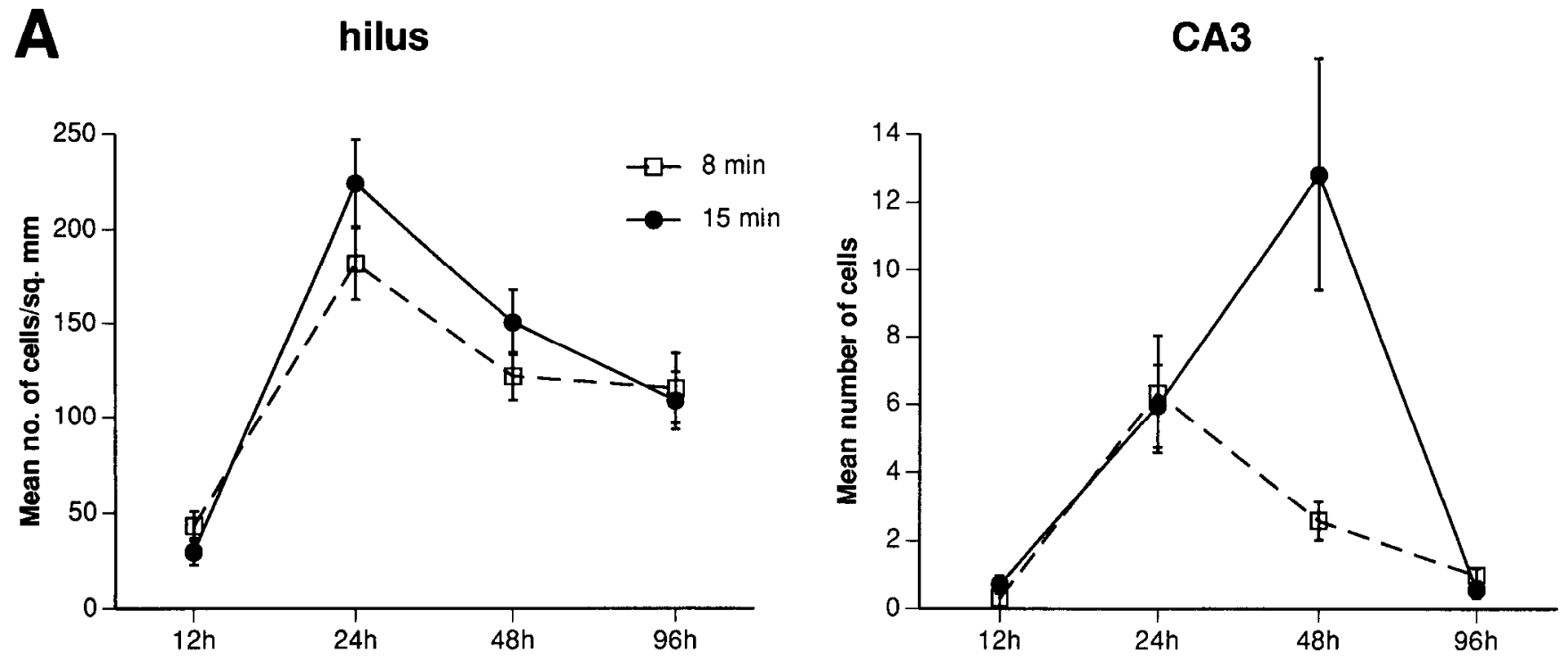

\section{survival}

B

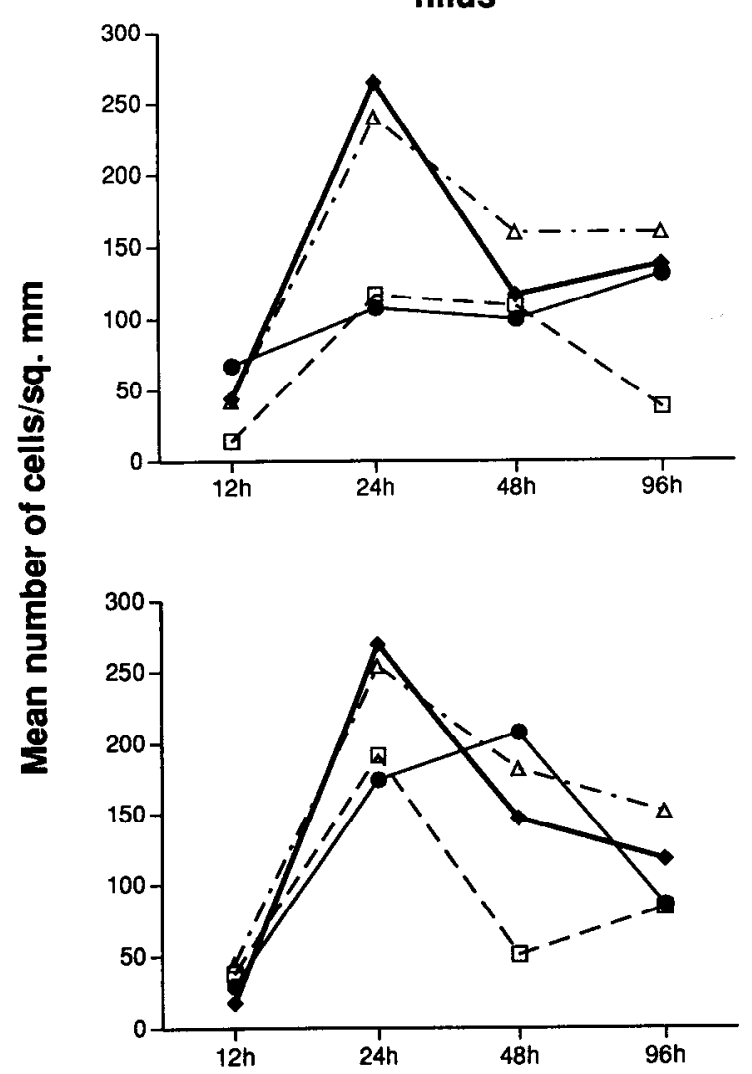

CA3

$8 \mathrm{~min}$

$15 \mathrm{~min}$

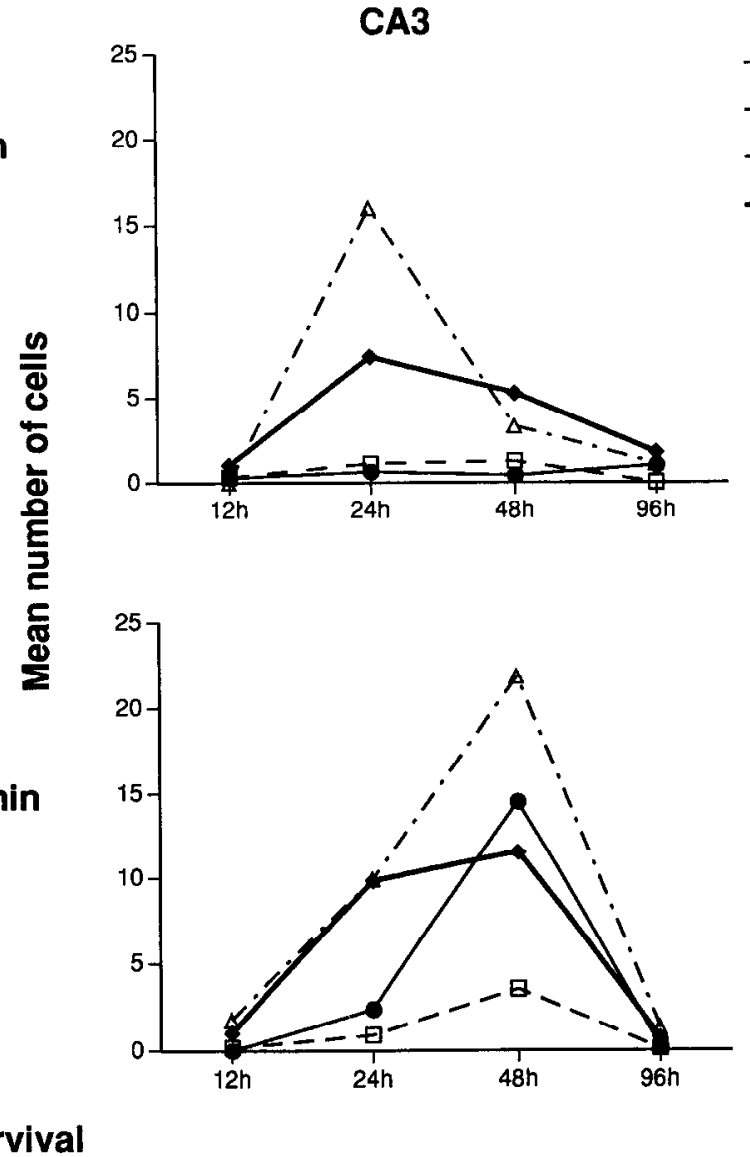

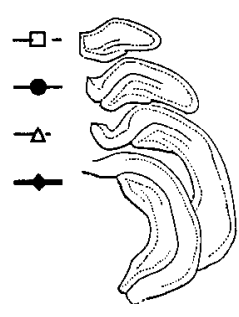

Figure 7. IISP72-immunopositive cell counts in the dentate hilus and CA3. Hilar cell counts are expressed as number of cells/mm ${ }^{2} ;$ CA3 cell counts are absolute numbers. $A$. Change in number of labeled hilar spiny cells $(l e f t)$ and CA3 spiny interneurons at different survival times. $B$, Change in hilar (left column) and CA3 (right column) cell counts in four sections (graph legend) along the rostral-caudal extent of the hippocampus $(\mathrm{AP}=-2.8,-3.8,-4.8$, and $-6.04 \mathrm{~mm})$. 

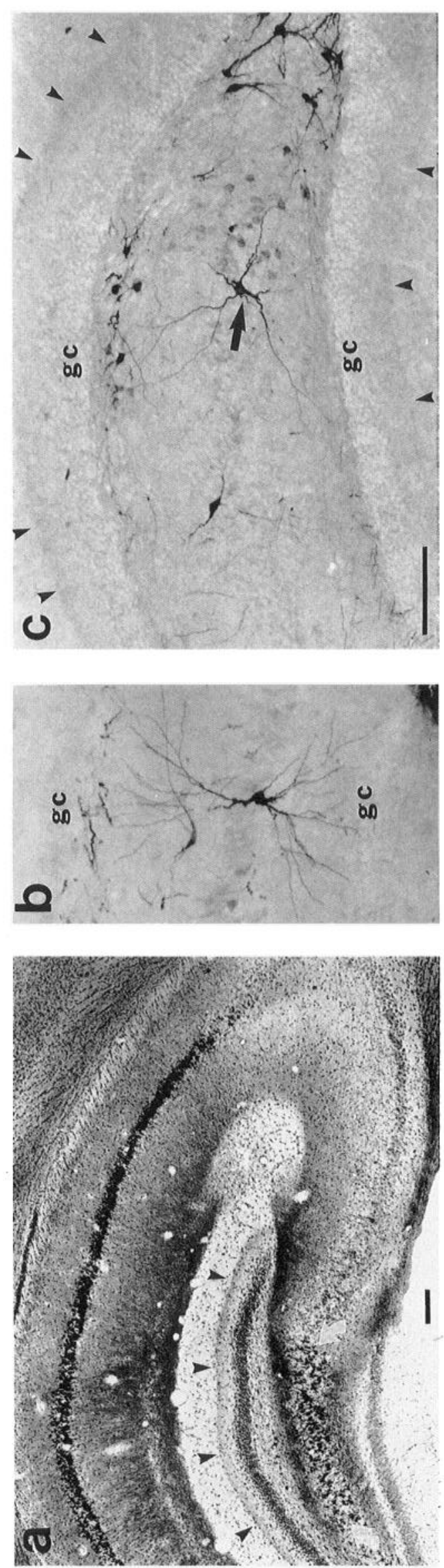
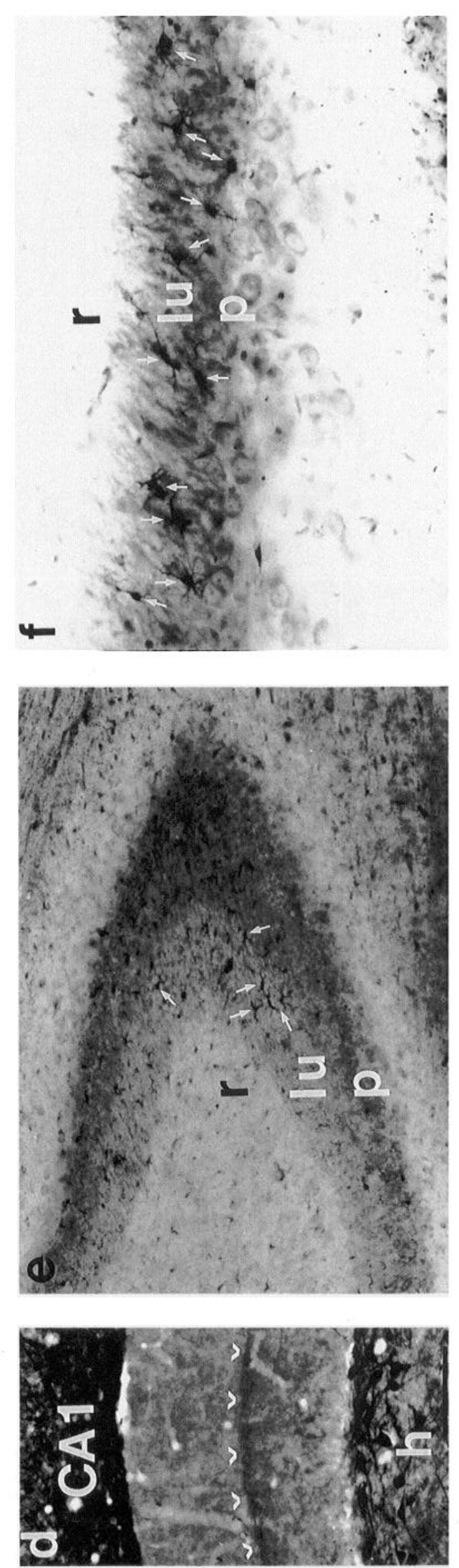

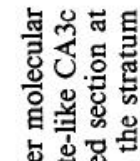

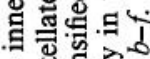

\% क ज्ञ

원.

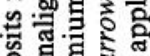

०ू द्र

ช 0.9

궁

के

규.

z

ํㅕㄹ

折

约 0. .

$>\infty$ o क क

녕

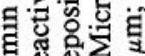

品羊

ㄱำ

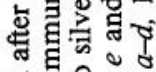

$\gamma . \rho^{2}$.

№을

สํㅜㅇ

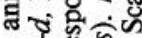

สํํㄹㄹ

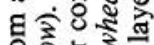

온

워

สำ 녹

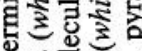

क

이욜

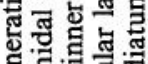

ㄹ.

近馬告

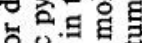

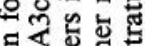

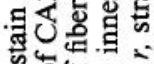

जि०

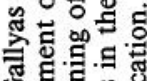

응 궁

o $>0$

ㄱ.

चั

등

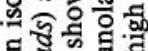

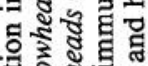

त्र

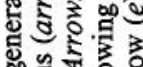

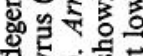

可

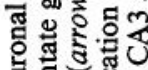

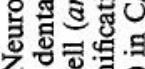

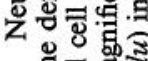

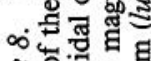

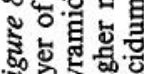



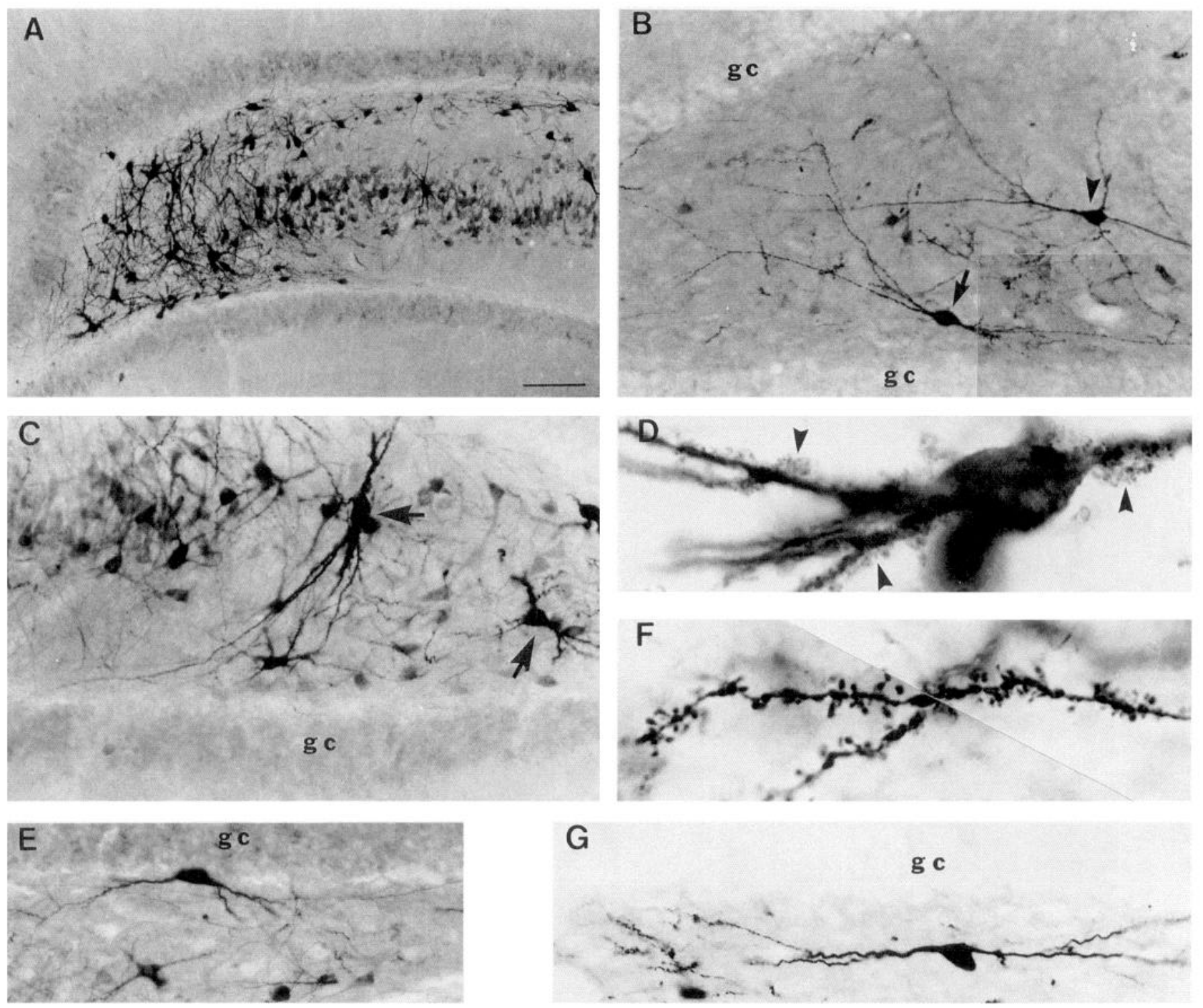

G
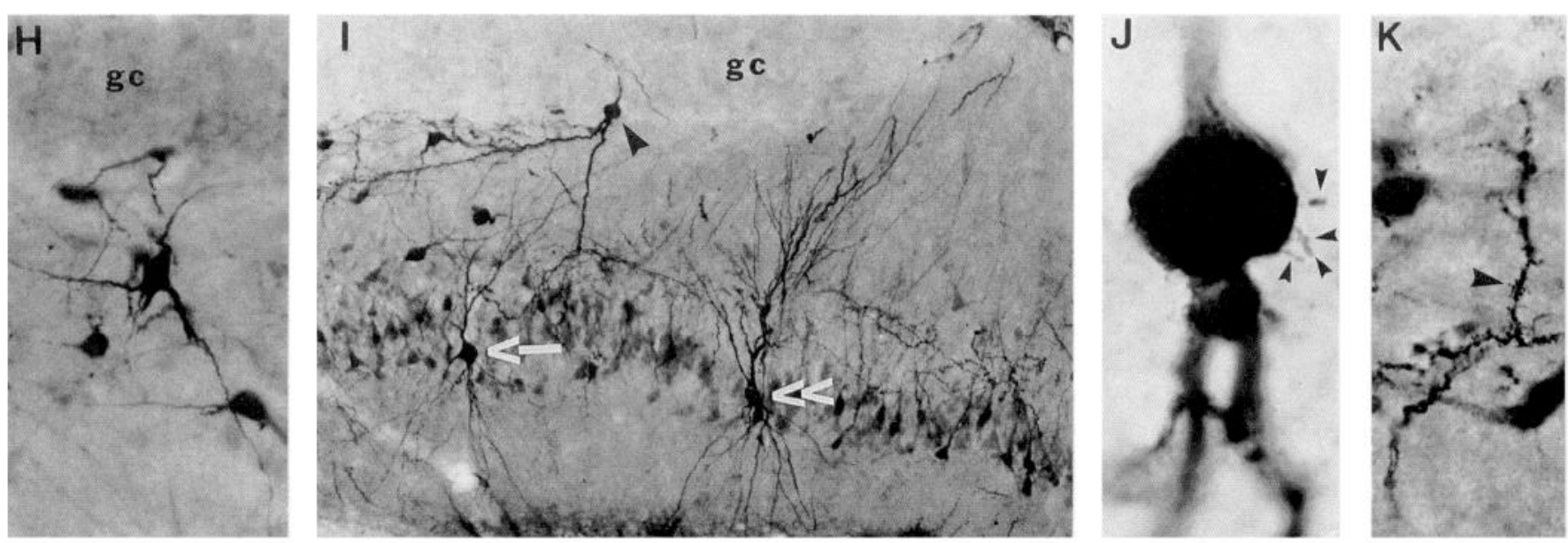

Figure 9. Hilar cells showing HSP72 immunoreactivity. $A$, Low-magnification photomicrograph showing extensive involvement of many cell types in the hilus. B, Oviform cell (arrow); unaligned pyramidal cell (arrowhead). $C$, Mossy cells (arrows). D, Higher magnification of large mossy cell on the left in $C$ showing characteristic "moss" on proximal dendrites (arrowheads). E, Spiny fusiform cell located below the granule cell layer. $F$, Spiny dendrites from the spiny fusiform cell in $E$. $G$, Sparsely spiny fusiform cell. $H$, Long-spined multipolar cell. $I$, Spheroid cell at the granule cell/hilus border (arrow) and pyramidal cells (white arrow and white double arrowhead). $J$ and $K$, Spines on the soma $(J)$ and dendrites $(K)$ of cell in $I$ (arrowheads). Scale bar: $100 \mu \mathrm{m}$ for $A$ and $I ; 50 \mu \mathrm{m}$ for $B, C, E$, and $H ; 10 \mu \mathrm{m}$ for $D, F, J$, and $K ; 25 \mu \mathrm{m}$ for $G$. 
degree of mossy fiber innervation predicts ischemic vulnerability in these two regions.

\section{Ischemic damage in CA3 interneurons and hilar neurons}

Previous studies have demonstrated a loss of somatostatin immunoreactivity in the dentate hilus after ischemia (Johansen et al., 1987, 1992; Grimaldi et al., 1990) and epilepsy (Sloviter, 1983; Sloviter and Nilaver, 1987). In addition, vulnerability of hilar mossy cells has also been implicated. To date, degenerating terminals located in the inner molecular layer have been the only evidence for the degeneration of mossy cells in the ischemic or epileptic hippocampus (Sloviter, 1987; Crain et al., 1988). However, apart from mossy cells, several other hilar cell types and modified pyramidal cells also project to the inner molecular layer of the dentate gyrus of the rat (Li et al., 1992; Han et al., 1993). Our results using three different techniques provide positive evidence that mossy cells are indeed compromised: degenerating terminals were found in the inner molecular layer of the dentate gyrus, many "dark" neurons in the hilus had the morphology of mossy cells, and the characteristic thorny excrescences revealed by HSP 72 immunocytochemistry positively identified these cclls as mossy cells. In fact, mossy cells were the most frequently immunolabeled cells.

In addition to mossy cells, many other different cell types were also immunoreactive for HSP72, including, in order of frequency of occurrence, spiny and sparsely spiny fusiform cells, long-spined multipolar cells, oviform cells, and spiny spheroid cells (Amaral, 1978; Ribak and Seress, 1988).

The mechanism of ischemic cell damage in the hilus is not well understood. In our study, a common feature of the hilar neurons immunoreactive for HSP72 was the presence of spines on their dendrites and/or cell bodies. It has recently been suggested that the somatostatin neurons correspond to the sparsely spiny fusiform cells (Han et al., 1993) originally described by Amaral (1978). However, the sparsely spiny fusiform cells comprised only a small portion of HSP72-immunoreactive neurons; the majority of the immunolabeled cells included several other types of spiny neurons. In contrast, none of the previously identified aspiny cells in the hilus (e.g., dentate basket cell, small aspiny multipolar cell, aspiny stellate cell) were immunoreactive for HSP72 or impregnated with silver. Many of the immunolabeled dendrites, especially at later survival periods ( 2 and 4 d), were swollen and vacuolated, reflecting overt damage of the cell membrane. With longer postischemic times, the spines lost their structural integrity and were no longer visible. Unevenly beaded and irregularly varicose dendrites were also apparent in our silver-stained material, providing further evidence that these cells were in the process of disintegration. These degenerative changes were similar in the spiny interneurons of the CA3 stratum lucidum and hilar neurons. Nevertheless, we should add that none of the described morphological alterations are unambiguous indicators of irreversible cell damage. Many neurons may recover despite serious injury to the dendritic spines and shafts. We can only conclude by inference that HSP72 expression and/or silver impregnation of neurons are predictors of eventual cell loss.

Several groups have proposed that neurons containing various calcium-binding proteins that buffer the cells against calcium increases are resistant to ischemic insults or to epilepsy (Scharfman and Schwartzkroin, 1989; Sloviter, 1989; Léránth and Ribak, 1991). However, neither the resistant CA3 pyramidal cells nor the vulnerable hilar somatostatin and mossy cells contain
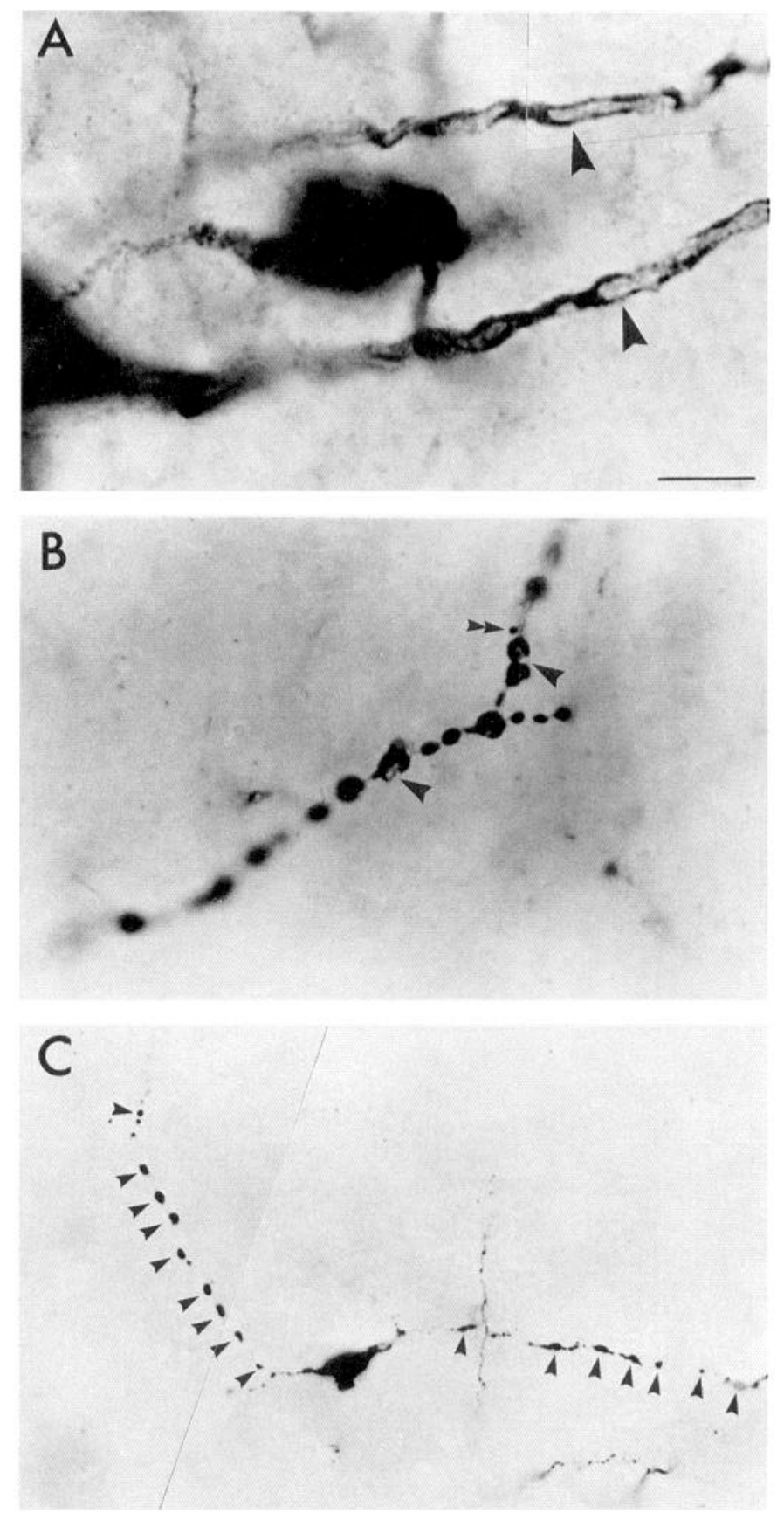

Figure 10. Pathological dendrites from degenerating hilar neurons. $A$ and $B$, HSP72 immunoreactivity. $A$, Vacuolated dendrites (arrowheads). B, Beaded dendrites (arrowheads). Double arrowhead points to a swollen spinehead. $C$, "Dark" neuron stain for traumatized neurons showing beaded dendrites (arrowheads). Note complete interruption of cytoplasm between the heads. Scale bar: $10 \mu \mathrm{m}$ for $A$ and $B ; 25 \mu \mathrm{m}$ for $C$.

any known calcium-binding proteins. Both the resistant granule cells and the sensitive CAl pyramidal cells, on the other hand, contain calbindin. Hippocampal neurons containing a second calcium-binding protein, parvalbumin, are resistant to ischemia. Parvalbumin-immunoreactive neurons in the striatum and reticular nucleus of the thalamus, however, are especially vulnerable (Freund et al., 1990). In our study, the spiny cells in the stratum lucidum and the long-spined multipolar cells in the hilus most likely correspond to the calretinin-immunoreactive 
cells of Gulyás et al. (1992). These cells are vulnerable to ischemia ( T. F. Freund, unpublished observations) and have not been shown to be colocalized with somatostatin. Furthermore, hilar mossy cells as well as the other cells we described using HSP72 immunocytochemistry do not contain calretinin. Even among calretinin-containing neurons, vulnerability to ischemia was not equal: aspiny calretinin-positive neurons found outside the stratum lucidum or the hilus were much less affected by ischemia (Freund, unpublished observations). Finally, somatostatin cells located outside the hilus are resistant. Thus, the heterogeneity of ischemia-sensitive neurons provides further proof that neither calcium-binding protein nor neuropeptide content reliably predicts ischemic vulnerability. We suggest that the common denominator shared by the ischemia-susceptible neurons in the hilus and CA3 region is the dense mossy fiber innervation they receive.

\section{Possible explanations for differential sensitivity to mossy fiber-mediated ischemic injury}

The mossy fiber system provides the major excitatory input to neurons in the hilus, pyramidal cells in CA3, and the spiny interneurons in the stratum lucidum of CA3 (Lorente de Nó, 1934; Gulyás et al., 1992). Excitatory synaptic transmission in this pathway is mediated primarily through kainate or AMPA receptors (Monaghan et al., 1983; Cotman et al., 1987). The mossy fiber termination zone in the stratum lucidum has very high levels of kainate receptors but low levels of NMDA sites (Cotman et al., 1987). This pathway has so far received little attention in investigations into the pathological mechanisms of ischemic cell damage perhaps because of the role accorded to NMDA receptors in mediation of ischenic cell death. However, even in area $\mathrm{CA} 1$, the exclusive involvement of NMDA receptors in mediating ischemic cell damage has been challenged recently. Much of the neuroprotective effects of NMDA antagonists in severe global ischemia (Simon et al., 1984; Gill et al., 1987; Swan et al., 1988; Ikonomidou et al., 1989; Olney et al., 1989) have now been attributed to hypothermia (Freund et al., 1989; Buchan and Pulsinelli, 1990; Corbett et al., 1990; Buchan et al., 1991a; Buchan, 1992). The emerging role of AMPA receptors in mediating ischemic cell death is supported by recent findings that administration of the AMPA antagonist 2,3-dihydroxy-6-nitro-7-sulfamoyl-benzo $(F)$ quinoxaline offers neuroprotection (Buchan et al., 1991 b; Buchan, 1992; Diemer et al., 1992; Nellgard and Wieloch, 1992).

The mossy fiber system also contains a high concentration of zinc (Danscher, 1981; Gaarskjaer, 1986). There is evidence that zinc may regulate both excitatory and inhibitory synaptic transmission (Assaf and Chung, 1984; Aniksztejn et al., 1987; Westbrook and Mayer, 1987; Xie and Smart, 1991), and zinc neurotoxicity has been demonstrated in cell cultures (Choi et al., 1988) and implicated in the selective death of dentate hilar neurons after cerebral ischemia (Tonder et al., 1990).

Even though mossy fiber system involvement in non-NMDAmediated ischemic cell death is likely, it is not clear why different subpopulations within the hilus and CA3 neurons (stratum lucidum spiny interneurons vs. pyramidal cells and other CA3 interneurons) are not equally sensitive to ischemia. We suggest that this differential vulnerability may be due to differences in mossy fiber innervation and/or different expression of glutamate receptor subtypes in the postsynaptic cells.

First, the density of mossy fiber innervation onto hilar cells and CA3 stratum lucidum interneurons is far greater than onto the CA3 pyramidal cells. A granule cell sends at least seven collaterals off its principal axon through the hilus forming contacts with many hilar neurons before making its way to CA3 (Claiborne et al., 1986). In area CA3, Gulyás et al. (1992) calculated that up to $10,000-20,000$ mossy fibers terminated onto a single stratum lucidum spiny interneuron whereas only $10-$ 50 mossy fibers terminated onto a CA3 pyramidal cell (Claiborne et al., 1986). Our observation that $C \wedge 3 \mathrm{c}$ pyramidal cells were also irreversibly damaged following longer durations of ischemia provides further support for the importance of the density of mossy fiber innervation because pyramidal cells in the CA $3 c$ subregion possess substantially more thorny excrescences and receive a greater number of mossy fiber terminals than their counterparts in the CA3b and CA3a subregions (Claiborne et al., 1986). Based on the currently available experimental evidence, we suggest that vulnerability of neurons in the hilus and $\mathrm{CA} 3$ region is a function of the density of mossy fiber innervation they receive. From this perspective, the circuitry in which the vulnerable neurons are located is the primary factor determining cell death, whereas other factors such as intracellular calcium buffering capacity probably play a secondary role.

An alternative explanation for the differential sensitivity of the mossy fiber targets may be sought in the different receptor subtypes of the vulnerable and resistant cell populations. Different cell targets of the mossy fiber system may express different subunit combinations of the same receptor complex that are either $\mathrm{Ca}^{2+}$ permeable or $\mathrm{Ca}^{2+}$ impermeable. It has recently been shown that the calcium permeability of kainate/AMPA-gated channels depends on the differential expression of the glutamate receptor subunits GluR1, GluR2, and GluR3 (Hollmann et al., 1991; Petralia and Wenthold, 1992). Cuexpression of GluR2 with either GluR1 or GluR3 results in $\mathrm{Ca}^{2+}$-impermeable channels, while channels expressing GluR1, GluR3, or GluR1 plus GluR3 form $\mathrm{Ca}^{2+}$-permeable channels. This suggestion is supported by electrophysiological studies showing the presence of two types of kainate responses in hippocampal neurons, $\mathrm{a} \mathrm{Ca}^{2+}$ impermeable type I response that had linear current-voltage properties and resembled GluR1 plus GluR2 or GluR3 plus GluR2 responses and a $\mathrm{Ca}^{2+}$-permeable type II response that was sigmoidal and resembled GluR1, GluR3, and GluR 1 plus GluR 3 responses (Iino et al., 1990). Spiny hilar neurons showed slow kinetics while aspiny hilar neurons showed fast kinetics in response to kainate (Livsey and Vicini, 1992). Finally, in area CA3, McBain and Dingledine (1993) were able to identify two types of interneurons based on their different kainate responses.

Combining the above information with our present findings, we suggest that the differential vulnerability seen between spiny interneurons and pyramidal cells in area CA3 and spiny and aspiny neurons in the hilus may be due to the absence of the GluR2 subunit in the vulnerable populations. Since channels lacking GluR2 subunits allow large influxes of $\mathrm{Ca}^{2+}$ on an order equivalent to NMDA ionophores (Hollmann et al., 1991), they may contribute to excitotoxicity. Along the same lines, Pellegrini-Giampietro et al. (1992) report a reduced GluR2 expression in postischemic CAl pyramidal cells preceding the increase in $\mathrm{Ca}^{++}$influx in the CAl cclls. Direct confirmation of our hypothesis requires the demonstration of a lack of GluR2 subunits on the vulnerable cell populations and the selective survival of neurons expressing GluR2 subunits after ischemia or a differential calcium permeability in the vulnerable versus resistant neuronal populations that are targets of the mossy fiber system. 


\section{Implications for delayed neuronal death in CAl pyramidal} neurons

It has been suggested that delayed neuronal death in area $\mathrm{CAl}$ is dependent upon a functional CA3 input (Benveniste et al., 1989). In light of the present findings, we speculate that the impairment of an important control mechanism in the CA3 region and hilus (spiny stratum lucidum and spiny hilar neurons) precedes and may be causal to delayed neuronal loss in CA1. This hypothesis may be tested by demonstrating the prevention of CA1 delayed neuronal death by pharmacological protection of the hilar and CA3 spiny cell types. In conclusion, the present findings demonstrate that substantially greater number of neuron types are involved in ischemia than previously thought. A common feature of these neurons is the dense innervation of their spiny dendrites by the mossy terminals of granule cells. Since the neuronal circuits of which they are a part (hilus $\rightarrow$ CA3) comprise the major input to CA1, examination of their causal involvement in the delayed neuronal death of CAI pyramidal cells is warranted.

\section{References}

Amaral DG (1978) A Golgi study of cell types in the hilar region of the hippocampus in the rat. J Comp Neurol 182:851-914.

Aniksztejn L, Charton G, Ben-Ari Y (1987) Selective release of endogenous zinc from the hippocampal mossy fibers in situ. Brain Res 404:58-64.

Assaf SY, Chung S-H (1984) Release of endogenous $\mathrm{Zn}^{2+}$ from brain tissue during activity. Nature 308:734-736.

Benveniste H, Drejer J, Schousboe A, Diemer NH (1984) Elevation of the extracellular concentrations of glutamate and aspartate in rat hippocampus during transient cerebral ischemia monitored by intracerebral microdialysis. J Neurochem 43:1369-1374.

Benveniste $H$, Jorgensen MB, Sandberg M, Christensen T, Hagberg $H$, Diemer NH (1989) Ischemic damage in hippocampal CAl is dependent on glutamate release and intact innervation from CA3. $J$ Cereb Blood Flow Metab 9:629-639.

Buchan AM (1992) Do NMDA antagonists prevent neuronal injury? No. Arch Neurol 29:420-421.

Buchan A, Pulsinelli WA (1990) Hypothermia but not the $N$-methylD-aspartate antagonist, MK-801, attenuates neuronal damage in gerbils subjected to transient global ischemia. J Neurosci 10:311-316.

Buchan A, Ii H, Pulsinelli WA (1991a) The $N$-methyl-D-aspartate antagonist, MK-801, fails to protect against neuronal damage caused by transient, severe forebrain ischemia in adult rats. J Neurosci 11: $1049-1056$

Buchan AM, Li H, Cho S, Pulsinelli WA (1991b) Blockade of the AMPA receptor prevents CA1 hippocampal injury following severe but transient forebrain ischemia in adult rats. Neurosci Lett 132:255258.

Buzsáki G, Freund TF, Bayardo F, Somogyi $P$ (1989) Ischemia-induced changes in the electrical activity of the hippocampus. Exp Brain Res 78:268-278.

Choi DW (1988) Glutamate neurotoxicity and diseases of the nervous system. Neuron 1:623-634.

Choi DW, Yokoyama M, Koh J (1988) Zinc neurotoxicity in cortical cell culture. Neuroscience 24:67-79

Chopp M, Li Y, Dereski MO, Levine SR, Yoshida Y, Garcia JH (1991) Neuronal injury and expression of $72-\mathrm{kDa}$ heat-shock protein after forcbrain ischemia in the rat. Acta Ncuropathol (Berl) 83:66-71.

Claiborne BJ, Amaral DG, Cowan WM (1986) A light and electron microscopic analysis of the mossy fibers of the rat dentate gyrus. $\mathbf{J}$ Comp Neurol 246:435-458.

Corbett D, Evans S, Thomas C, Wang D, Jonas RA (1990) MK-801 reduced cerebral ischemia injury by inducing hypothermia. Brain Res 514:300-304.

Cotman CW, Monaghan DT, Ottersen OP, Storm-Mathisen J (1987) Anatomical organization of excitatory amino acid receptors and their pathways. Trends Neurosci 10:273-280.

Crain BJ, Westerkam WD, Harrison AH, Nadler JV (1988) Selective neuronal death after transient forebrain ischemia in the mongolian gerbil: a silver impregnation study. Neuroscience 27:387-402.

Danscher G (1981) Histochemical demonstration of heavy metals. A revised version of the sulphide silver method suitable for both light and electronmicroscopy. Histochemistry 71:1-16.

Diemer NH, Jorgensen MB, Johansen FF, Sheardown M, Honore T (1992) Protection against ischemic hippocampal CAl damage in the rat with a new non-NMDA antagonist, NBQX. Acta Neurol Scand $86: 45 \sim 49$.

Dienel GA, Kiessling M, Jacewicz M, Pulsinelli WA (1986) Synthesis of heat shock proteins in rat brain cortex after transient ischemia. $J$ Ccreb Blood Flow Mctab 6:505-510.

Dwyer BE, Nishimura RN, Brown IR (1989) Synthesis of the major inducible heat shock protein in rat hippocampus after neonatal hypoxia-ischemia. Exp Neurol 104:28-31.

Freund TF, Buzsáki G, Prohaska OJ, Leon A, Somogyi P (1989) Simultaneous recording of local electrical activity, partial oxygen tension and temperature in the rat hippocampus with a chamber-type microelectrode. Effects of anaesthesia, ischemia and epilepsy. Neuroscience 28:539-549.

Freund TF, Buzsáki G, Leon A, Baimbridge KG, Somogyi P (1990) Relationship of neuronal vulnerability and calcium binding protein immunoreactivity in ischemia. Exp Brain Res 83:55-66.

Freund TF, Ylinen A, Miettinen R, Pitkänen A, Lahtinen H, Baimbridge KG, Riekkinen PJ (1991) Pattern of neuronal death in the rat hippocampus after status epilepticus. Relationship to calcium binding protein content and ischemic vulnerability. Brain Res Bull 28:27-38.

Frotscher M, Seress L, Schwerdtfeger WK, Buhl E (1991) The mossy cells of the fascia dentata: a comparative study of their fine structure and synaptic connections in rodents and primates. J Comp Neurol 312:145-163.

Gaarskjaer FB (1986) The organization and development of the hippocampal mossy fiber system. Brain Res Rev 11:335-357.

Gallyas F, Wolff JR, Bottcher H, Zabroszky L (1980) A reliable method demonstrating axonal degeneration shortly after axotomy. Stain Technol 55:291-297.

Gallyas F, Güldner FH, Zoltay G, Wolff JR (1990) Golgi-like demonstration of "dark" neurons with an argyrophil III method for experimental neuropathology. Acta Neuropathol (Berl) 79:620-628.

Gill R, Foster AC, Woodruf GN (1987) Systemic administration of MK-801 protects against ischemia-induced hippocampal neurodegeneration in the gerbil. $J$ Neurosci 7:3343-3349.

Gonzalez MF, Lowenstein D, Fernyak S, Hisanaga K, Simon R, Sharp FR (1991) Induction of heat shock protein 72-like immunoreactivity in the hippocampal formation following transient global ischemia. Brain Res Bull 26:24l-250.

Greenamyre JT (1986) The role of glutamate in neurotransmission and in neurologic disease. Arch Neurol 43:1058-1063.

Grimaldi R, Zoli M, Agnati LF, Ferraguti F, Fuxe K, Toffano G, Zini I (1990) Effects of transient forebrain ischemia on peptidergic neurons and astroglial cells: evidence for recovery of peptide immunoreactivities in the neocortex and striatum but not hippocampal formation. Exp Brain Res 82:123-136.

Gulyás A, Miettinen R, Jacobowitz DM, Freund TF (1992) Calretinin is present in non-pyramidal cells of the rat hippocampus. I. A new type of neuron specifically associated with the mossy fibre system. Neuroscience 48:1-27.

Han Z-S, Buhl EH, Lörinczi Z, Somogyi P (1993) A high degree of spatial selectivity in the axonal and dendritic domains of physiologically identified local-circuit neurones in the dentate gyrus of the rat hippocampus. Eur $\mathrm{J}$ Neurosci, in press.

Hollmann M, Hartley M, Heinemann S (1991) $\mathrm{Ca}^{2+}$ permeability of KA-AMPA-gated glutamate receptor channels depends on subunit composition. Science 252:851-853.

Iino M, Ozawa S, Tsuzuki K (1990) Permeation of calcium through excitatory amino acid receptor channels in cultured rat hippocampal neurones. J Physiol (Lond) 424:151-165.

Ikonomidou C, Price MT, Mosinger JL, Frierdich G, Labruyere J, Shahid Salles K, Olney JW (1989) Hypobaric-ischemic conditions produce glutamate-like cytopathology in infant rat brain. J Neurosci 9:1693-1700.

Imon H, Mitani A, Anoud Y, Arai T, Kataoka K (1991) Delayed neuronal death is induced without postischemic hyperexcitability: continuous multiple-unit recording from ischemic CA1 neurons. J Cereb Blood Flow Metab 11:819-823. 
Jensen MS, Lambert JDC, Johansen FF (1991) Electrophysiological recordings from rat hippocampus slices following in vivo brain ischemia. Brain Res 554:166-175.

Johansen FF, Jørgensen MB, Diemer NH (1983) Resistance of hippocampal CA-1 interneurons to $20 \mathrm{~min}$ of transient cerebral ischemia in the rat. Acta Neuropathol (Berl) 61:135-140.

Johansen FF, Jørgensen MB, Diemer NH (1986) Ischemic CA-1 pyramidal cell loss is prevented by preischemic colchicine destruction of dentate gyrus granule cells. Brain Res 377:344-347.

Johansen FF, Zimmer J, Diemer NH (1987) Early loss of somatostatin neurons in dentate hilus after cerebral ischemia in the rat precedes CA-1 pyramidal cell loss. Acta Neuropathol (Berl) 73:110-114.

Johansen FF, Tonder $\mathbf{N}$, Zimmer J, Baimbridge KG, Diemer $\mathrm{NH}$ (1990) Short-term changes of parvalbumin and calbindin immunoreactivity in the rat hippocampus following cerebral ischemia. Neurosci Lett 120:171-174.

Johansen FF, Sorensen T, Tonder N, Zimmer J, Diemer NH (1992) IJtrastructure of neurons containing somatostatin in the dentate hilus of the rat hippocampus after cerebral ischaemia, and a note on their commissural connections. Neuropathol Appl Neurobiol 18:145-157.

Kaplan TM, Lasner TM, Nadler JV, Crain BJ (1989) Lesions of excitatory pathways reduce hippocampal cell death after transient forebrain ischemia in the gerbil. Acta Neuropathol (Berl) 78:283-290.

Kirino $T$ (1982) Delayed neuronal death in the gerbil hippocampus following ischemia. Brain Res 239:57-69.

Kirino T, Tamura A, Sano K (1985) Selective vulnerability of the hippocampus to ischemia-reversible and irreversible types of ischemic cell damage. In: (Kogure K, Hossman K-A, Siesjö BK, Welsh FA, eds), pp 39-58. New York: Elsevier.

Léránth C, Ribak CE (1991) Calcium-binding proteins are concentrated in the CA2 field of the monkey hippocampus: a possible key to this region's resistance to epileptic damage. Exp Brain Res 85:129136.

Li X-G, Tepper JM, Jandó G, Buzsáki G (1992) Axon arborization of $\mathrm{CA} 3$ pyramidal cclls in vivo: an intraccllular labcling study. Soc Neurosci Abstr 18:320.

Livsey CT, Vicini S (1992) Slower spontaneous excitatory postsynaptic currents in spiny versus aspiny hilar neurons. Neuron 8:745-755.

Lorente de Nó R (1934) Studies on the structure of the cerebral cortex. II. Continuation of the study of the Ammonic system. J Psychol Neurol 46:113-176.

MacDermott AB, Mayer ML, Westbrook GL, Smith SJ, Barker JL (1986) NMDA-receptor activation increases cytoplasmic calcium concentration in cultured spinal cord neurones. Nature 321:519-522.

McBain CJ, Dingledine R (1993) Heterogeneity of synaptic glutamate receptors on CA3 st. radiatum interneurones of rat hippocampus. $J$ Physiol (Lond) 462:373-392.

Monaghan DT, Holets VR, Toy DW, Cotman CW (1983) Anatomical distributions of four pharmacologically distinct ${ }_{3}$ II-L-glutamate binding sites. Nature 306:176-179.

Nellgård B, Wieloch T (1992) Postischemic blockade of AMPA but not NMDA receptors mitigates neuronal damage in the rat brain following transient severe cerebral ischemia. J Cereb Blood Flow Metab 12:2-11.

Nitsch C, Goping G, Klatzo I (1989a) Preservation of GABAergic perikarya and boutons after transient ischemia in the gerbil hippocampal CA1 field. Brain Res 495:243-252.

Nitsch C, Scotti A, Sommacal A, Kalt G (1989b) GABAergic hippocampal neurons resistant to ischemia-induced neuronal death contain the $\mathrm{Ca}^{2+}$-binding protein parvalbumin. Neurosci Lett 105:263268.

Nowak TS Jr (1985) Synthesis of a stress protein following transient ischemia in the gerbil. J Neurochem 45:1635-1641.

Olney JW (1978) Neurotoxicity of excitatory amino acids. In: Kainic acid as a tool in neurobiology (McGeer EG, Olney JW, McGeer PL, eds), pp 37-70. New York: Raven.

Olney JW, Ikonomidou C, Mosinger JL, Frierdich G (1989) MK-801 prevents hypobaric-ischemic neuronal degeneration in infant rat brain. J Neurosci 9:1701-1704.

Paxinos G, Watson C (1986) The rat brain in stereotaxic coordinates. San Diego: Academic.

Pelham HRB (1986) Speculations on the functions of the major heat shock and glucose-regulated proteins. Cell 46:959-961.

Pellegrini-Giampietro DE, Zukin RS, Cho S, Pulsinelli WA (1992) Switch in kainate/AMPA receptor subunit gene expression following global ischemia in rats. Soc Neurosci Abstr 19:89.
Petralia RS, Wenthold RJ (1992) Light and electron immunocytochemical localization of AMPA-selective glutamate receptors in the rat brain. J Comp Neurol 318:329-354.

Pulsinelli WA, Brierley JB (1979) A new model of bilateral hemispheric ischemia in the unanesthetized rat. Stroke 10:267-272.

Pulsinelli WA, Buchan A (1988) The four-vessel occlusion rat model: methods for complete occlusion of vertebral arteries and control of collateral circulation. Stroke 19:913-914.

Pulsinelli WA, Brierley JB, Plum F (1982) Temporal profile of neuronal damage in a model of transient forebrain ischemia. Ann Ncurol $11: 491-498$.

Ribak CE, Seress L (1988) A Golgi-electron microscopic study of fusiform neurons in the hilar region of the dentate gyrus. J Comp Neurol 217:67-78.

Scharfman HE, Schwartzkroin PA (1989) Protection of dentate hilar cells from prolonged stimulation by intracellular calcium chelation. Science 246:257-260.

Schmidt-Kastner R, Freund TF (1991) Selective vulnerability of the hippocampus in brain ischemia. Neuroscience 40:599-636.

Siesjö BK, Bengtsson F (1989) Calcium fluxes, calcium antagonists, and calcium-related pathology in brain ischemia, hypoglycemia, and spreading depression: a unifying hypothesis. J Cereb Blood Flow Metab 9:127-140.

Simon RP, Swan J, Griffith T, Meldrum B (1984) Blockade of $N$-methyl-D-aspartate receptors may protect against ischemic damage in the brain. Science 226:850-852.

Simon RP, Cho H, Gwinn R, Lowenstein DH (1991) The temporal profile of 72-kDa heat-shock protein expression following global ischemia. J Neurosci 11:881-889.

Sloviter RS (1982) A simplified Timm stain procedure compatible with formaldehyde fixation and routine paraffin embedding of rat brain. Brain Res Bull 8:771-774.

Sloviter RS (1983) "Epileptic" brain damage in rats induced by sustained electrical stimulation of the perforant path. I. Acute electrophysiological and light microscopic studies. Brain Res Bull 10:675697.

Sloviter RS (1987) Decreased hippocampal inhibition and a selective loss of interneurons in experimental epilepsy. Science 235:73-76.

Sloviter RS (1989) Calcium-binding protein (calbindin-D28k) and parvalbumin immunocytochemistry: localization in the rat hippocampus with specific reference to the selective vulnerability of hippocampal neurons to seizure activity. J Comp Neurol 280:183-196.

Sloviter RS, Lowenstein DH (1992) Heat shock protein expression in vulnerable cells of the rat hippocampus as an indicator of excitationinduced neuronal stress. J Neurosci 12:3004-3009.

Sloviter RS, Nilaver G (1987) Immunocytochemical localization of GABA-, cholecystokinin-, vasoactive intestinal polypeptide-, and somatostatin-like immunoreactivity in the area dentata and hippocampus of the rat. J Comp Neurol 256:42-60.

Swan J, Evans M, Meldrum B (1988) Long-term development of selective neuronal loss and the mechanism of protection by 2-amino7-phosphonoheptanoic acid in a rat model of incomplete forebrain ischemia. J Cereb Blood Flow Metab 8:64-78.

Tønder N, Johansen FF, Frederickson CJ, Zimmer J, Diemer NH (1990) Possible role of zinc in the selective degeneration of dentate hilar neurons after cerebral ischemia in the adult rat. Neurosci Lett 109:247-252.

Van den Pol AN, Gallyas F (1990) Trauma-induced Golgi-like staining of neurons: a new approach to neuronal organization and response to injury. J Comp Neurol 296:654-673.

Vass K, Welch WJ, Nowak TS Jr (1988) Localization of 70-kDa stress protein induction in gerbil brain after ischemia. Acta Neuropathol (Bcrl) 77:128-135.

Vass K, Berger ML Jr, Nowak TS, Welch WJ, Lassmann H (1989) Induction of stress protein HSP70 in nerve cells after status epilepticus in the rat. Neurosci Lett 100:259-264.

Vincent SR, Johansson O, Hökfelt T, Skirboll L, Elde RP, Terenius L, Kimmel J, Goldstein M (1983) NADPH-diaphrase: a selective histochemical marker for striatal neurons containing both somatostatinand avian pancreatic polypeptide (AP)-like immunoreactivities. $J$ Comp Neurol 217:252-263.

Westbrook GL, Mayer ML (1987) Micromolar concentrations of $\mathrm{Zn}^{2+}$ antagonize NMDA and GABA responses of hippocampal neurons. Nature 328:640-643.

Xie X, Smart TG (1991) A physiological role for endogenous zinc in rat hippocampal synaptic neurotransmission. Nature 349:521-524. 
Yanagihara T, Yoshimine T, Morimoto K, Yamamoto K, Homburger HA (1985) Immunohistochemical investigation of cerebral ischemia in gerbils. J Neuropathol Exp Neurol 44:204-215.

7ola-Morgan S, Squire LR, Amaral DG (1986) Human amnesia and the medial temporal region: enduring memory impairment following a bilateral lesion limited to field CAl of the hippocampus. J Neurosci 6:2950-2967.

Zola-Morgan S, Squire LR, Rempel NL, Clower RP, Amaral DG (1992) Enduring memory impairment in monkeys after ischemic damage to the hippocampus. J Neurosci 12:2582-2596. 